\title{
Die huwelik in die eerste-eeuse Mediterreense wêreld (III): Jesus en die huwelik
}

\author{
Ernest van Eck ${ }^{1}$ \\ Departement Nuwe-Testamentiese Wetenskap \\ Universiteit van Pretoria
}

\begin{abstract}
Marriage in the first-century Mediterranean world (III): Jesus and marriage

This article is the third in a three-part series that aims to stimulate the hermeneutical debate in the church regarding marriage as Biblical institution. In the first article attention was given to the relevant cultural scripts that are necessary to understand the institution of marriage in the time of Jesus. In the second article a description of what marriage, betrothal, adultery, divorce and remarriage in the first-century Mediterranean world entailed was given. In this article Jesus' point of view on marriage is investigated. The conclusion reached is that Jesus' stance towards marriage was negative. This, however, does not mean that Jesus had nothing to say as far as marriage as institution in a postmodern society is concerned.
\end{abstract}

\section{INLEIDING}

1 Korintiërs 11:13 stel dat dit onbetaamlik vir 'n vrou is om sonder iets op haar kop in die erediens tot God te bid. Met enkele uitsonderings na, dra hierdie opdrag van Paulus vandag weinig gewig. 1 Korintiërs 14:34 stel verder dat vrouens nie toegelaat word om in die erediens te praat nie. Tog legitimeer die Kerk vandag vroue in die ampte, ook in die amp van predikant. Om die waarheid te sê, elke Sondag in die erediens luister vroue sonder enige vorm van hoofbedekking na die verkondiging van die evangelie, en die stem wat die evangelieboodskap dra is dikwels die van 'n vrou.

Is die rede vir hierdie "gemaklike" opsy skuif van bogenoemde twee uitsprake van Paulus die gevolg van 'n interpretasie van die Bybel wat

\footnotetext{
${ }^{1}$ Rede by geleentheid van die jaaropening van die Hervormde Teologiese Kollege, Fakulteit Teologie, Universiteit van Pretoria, op 30 Januarie 2007.
} 
hermeneuties opereer met "n kanon in die kanon"? Of is dit die gevolg van die insig dat kultuur en kanon, of dan, kultuur en evangelie, nie met mekaar verwar of vermeng moet word nie? Wallace (2006:84) maak in hierdie verband die volgende opmerking: "[T]he burden of discerning the truth of the Bible can only be handled - as Luther always insisted ... - by readers who self-consciously take a particular interpretive stance towards the Bible in the light of their own 'working canon' or 'hermeneutical template'"(Wallace 2006:84).

In wat volg dien die volgende as "working canon", of dan, "hermeneutical template": in 'n poging om nie etnosentristies of anakronisties met die Bybelse teks om te gaan nie, word erns met ' $n$ kultuur-kritiese lees van die ter sake tekste gemaak. Meer spesifiek word 'n sosiaalwetenskaplike lees van die teks ingespan in 'n poging om tussen dit wat kontingent (kultuur) en noodwendig (evangelie) in die teks is, te onderskei.

In die tweede plek word die teks bewustelik hermeneuties benader, nie met ' $n$ "kanon in die kanon" nie, maar met 'n "kanon agter die kanon" (kyk Marxsen 1986:284; Van Aarde 2001b:148:171), dit wil sê, die verkondigende Jesus (historiese Jesus), of dan die Jesus-saak. Wat die inhoudelike van die Jesus-saak betref, word aanvaar dat die vroeë Jesus-beweging in beginsel anti-hiërargies, nie-seksisties en inklusief van karakter was.

Derdens word hermeneuties van die oortuiging uitgegaan dat wat ons in die Evangelies (en Paulus) vind, soms (en miskien dikwels) 'n vervreemding van die Jesus-saak is. Bogenoemde twee voorbeelde in Paulus se brief aan die Korintiërs is 'n goeie voorbeeld hiervan. Wat die Evangelies betref, is die saak van vervreemding van die verkondiging van die verkondigende Jesus miskien 'n bietjie meer ingewikkeld: nie alleen is outentieke Jesus-woorde deur die proses van mondelinge oorlewering op verskeie wyses aangepas ten dienste van die vroeë Jesus-beweging nie, maar ook is dit wat Jesus gesê het deur elke evangelis redaksioneel in die vorm van 'n vertelling neergepen in terme van 'n eie en spesifieke konteks (kyk o a Funk, Hoover \& The Jesus Seminar 1993:19-34).

In kort kom dit daarop neer dat Jesus se uitsprake oor die huwelik, egbreuk, egskeiding en hertrou in Q 16:18 (Luk 16:18 en Matt 5:31-32), Markus 10:2-12 en parallel (Matt 19:3-12) nie maar net as "the plain sense of Scripture" beskou kan word nie. Alleen 'n etnosentristiese lees, en 'n gepaardgaande vermenging van kultuur en evangelie kan die gevolg van sodanige hermeneutiese ingesteldheid wees. In die onderhawige rede word daarom gepoog om, in soverre dit moontlik is, die outentieke Jesus-logia ten opsigte van die huwelik te identifiseer en as basis te gebruik om Jesus se beskouing van die huwelik daar te stel. 
Die struktuur van die onderhawige rede is soos volg: na 'n kort beskrywing van die beskouing van die huwelik die eerste-eeuse Mediterreense wêreld, word daar gepoog om die outentieke Jesus-logia ten opsigte van die huwelik te identifiseer. Vervolgens word 'n kort beskrywing van die mees resente navorsing oor Jesus se beskouing van die huwelik aangebied, waarna die tese dat Jesus se beskouing van die huwelik nie losgemaak kan word van sy beskouing van die familie nie, beredeneer word. Ten slotte word Jesus se beskouing van die huwelik, as resultaat van bogenoemde studie, aangebied.

\section{DIE HUWELIK IN DIE EERSTE-EEUSE MEDITERREENSE WÊRELD EN JESUS}

\subsection{Die huwelik in die tyd van Jesus}

Die huwelik in die tyd van Jesus het soos volg daaruit gesien (kyk Van Eck 2007a:81-101; 2007b:103-128): Die huwelik tussen twee individue was 'n reëling tussen twee families. Die uitoefening van die keuse van huwelikmaats deur die betrokke man en vrou het dus nie bestaan nie. Bepaalde magsbelange het ten grondslag van die huwelik gelê (bv polities of ekonomies). Die huwelik was patriargaal, patrilokaal, hiërargies, poligamies en endogamies van aard. Laasgenoemde het verband gehou met die defensiewe huwelikstrategie wat tipies was van die tweede tempeltydperk (en dus ook van die eerste-eeuse Mediterreense wêreld en die Nuwe Testament). Seksuele kontak was uitsluitlik gerig op prokreasie, en dogters gebore uit 'n huwelik was belangrike (onderhandelings)middele waarmee magsbelange gedien is. Man en vrou het in duidelik sosiaal afgebakende ruimtes beweeg wat net soms oorvleuel het. Persoonlike kontak was dus min. Die eersteeeuse Mediterreense wêreld se beskouing van persoonlikheid as diadies het verder nie ruimte gelaat vir die emosionele en psigologiese fasette van menswees en persoonlike verhoudings nie. Vir die vrou het dit alles beteken dat sy soos 'n "vreemdeling" in haar man se huis gewoon het.

Egbreuk was gesien as die "steel" van 'n ander man se besitting of eer - daarom kon die man nooit egbreuk teenoor sy vrou pleeg nie (alleenlik "buite" sy huwelik). Die vrou kon egter egbreuk teenoor haar man pleeg. Net die man kon egskeiding inisieer, en egskeiding het plaasgevind by wyse van die uitreiking van 'n skeibrief. Egskeiding was die omkering van die proses van huweliksluiting tussen twee families: tydens die proses van huweliksluiting is twee families kontraktueel aan mekaar gebind, en met egskeiding is hierdie ooreengekome kontrak met mekaar ontbind. Die gee van 'n skeibrief het die vrou van die eer van haar man losgemaak, en aan haar die reg gegee om weer 'n huwelik aan te gaan. 


\subsection{Wat het Jesus oor die huwelik gesê?}

Jesus se uitsprake wat verband kan hou met die huwelik (en verwante aangeleenthede soos die leviraathuwelik, egbreuk, egskeiding en hertrou) kom voor in Markus 12:18-27 en parallelle (Matt 22:23-33; Luk 20:27-40), Q 16:18 (Luk 16:18 en Matt 5:31-32), Markus 10:2-12 en parallel (Matt 19:3-12), en Matteus 5:27-28.

Volgens Crossan (1991:301-302, 434-435) kan uit bogenoemde tekste Q 16:18, Markus 10:2-12 en Matteus 19:3-12 heel waarskynlik teruggevoer word na uitsprake van Jesus wat in verband met die huwelik gebring kan word. In terme van die beginsel van onafhanklike getuienis kom hierdie uitsprake van Jesus ook in 1 Korintiërs $7: 10-11^{2}$ en die Pastor van Hermas

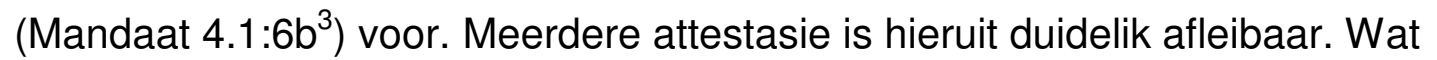
betref kronologiese stratifikasie kan 1 Korintiërs en $Q$ heel waarskynlik in die vroegste strata geplaas word (voor $60 \mathrm{nC}$ ), en Markus voor $80 \mathrm{nC}$ (kyk Crossan 1991:427-430).

Matteus 5:27-28 en Markus 12:18-27 word dus beoordeel as uitsprake in die Sinoptiese evangelies wat nie na Jesus teruggevoer kan word nie. Matteus 5:27-28 is die tweede antitese van die ses antiteses in Matteus 5:2148. Die patroon tese-antitese ("julle het gehoor dat daar gesê is" en "maar ek sê vir julle") het geen parallel in enige ander uitsprake van Jesus nie, en is heel waarskynlik 'n konstruksie van of Matteus of 'n struktuur wat Matteus uit die mondelinge tradisie van die vroeë geloofsgemeenskap oorgeneem het (Funk et al 1993:141). Die gebruik van die "goddelike negatief" (daar is gesê = God het gesê) kom dikwels in rabbynse literatuur voor (Harrington 1991:86), en dui op die sterk Joodse agtergrond van Matteus (kyk Harrington 1991:8-16; Van Eck 2006:5). Die patroon van "wat die Skrifte sê" teenoor "dit wat Jesus sê" kan heel waarskynlik ook teen die agtergrond van die "Joodsheid" van Matteus verstaan word. ${ }^{4}$ Ook Markus 12:18-27 kan heel waarskynlik nie na Jesus en sy uitsprake wat verband hou met die huwelik teruggevoer word nie. Die styl van hierdie vertelling is tipies rabbinies van aard (die bespreking van 'n probleem op grond van 'n aanhaling uit die Skrifte), en die woorde van

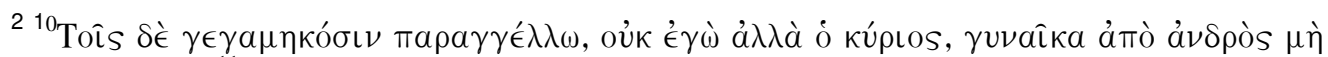

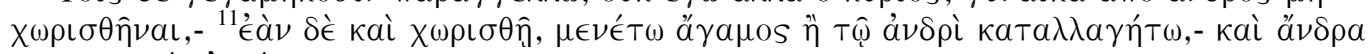

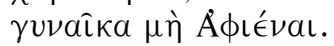

${ }^{36 \mathrm{~b}}$ Maar as hy van sy vrou skei en met 'n ander een trou, pleeg hy ook egbreuk (vertaling deur my; kyk Crossan 1986:30).

${ }^{4}$ Navorsers wys gewoonlik op die volgende eienskappe in Matteus wat dui op die sogenaamde "Joodsheid" van die evangelie (kyk Van Eck 2006:4): klem op Jesus as die messias wat in die Ou Testament voorspel word, verskeie vervullingsitate in Matteus (vgl Matt $1: 23 ; 2: 6 ; 4: 14-16$ ), die begrip koninkryk van God wat met die begrip koninkryk van die hemel vervang word, klem op die blywende geldigheid van die wet (Matt 5:17), die struktuur van die Matteus (verhalende gedeeltes word onderbreek deur vyf redevoeringe van Jesus, analogies

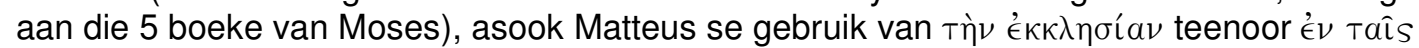
$\sigma v \nu a \gamma \omega \gamma a \hat{s} s \dot{v} \mu \hat{\omega} \nu$ (in julle sinagoges).
} 
Jesus (Mark 12:24-27) is duidelik deel van die struktuur van die groter vertelling (Funk et al 1993:105). Die agtergrond van hierdie vertelling lê heel waarskynlik in die vroeë geloofsgemeenskap in Palestina se konflik met die Fariseërs en ander groepe. 'n Parallelle vergelyking van die ter sake uitsprake van Jesus in Q 16:18, Markus 10:2-12 en Matteus 19-3-12 oor die huwelik sien soos volg daaruit:

\begin{tabular}{|c|c|}
\hline Markus 10:5-9 & Matteus 19:4-6, 8 \\
\hline 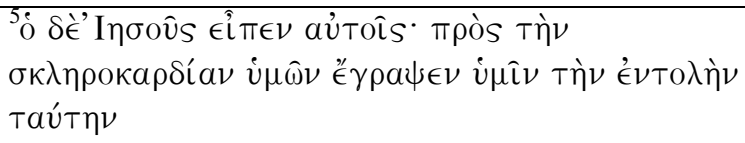 & 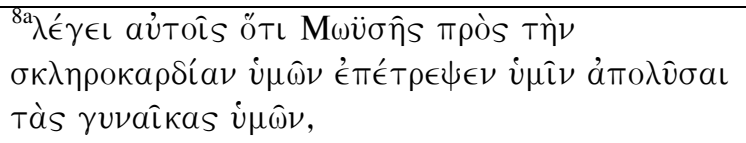 \\
\hline 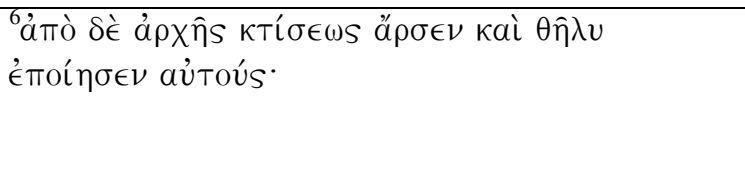 & 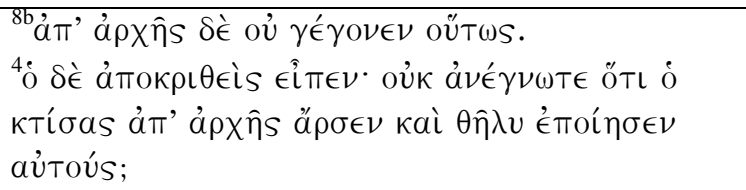 \\
\hline 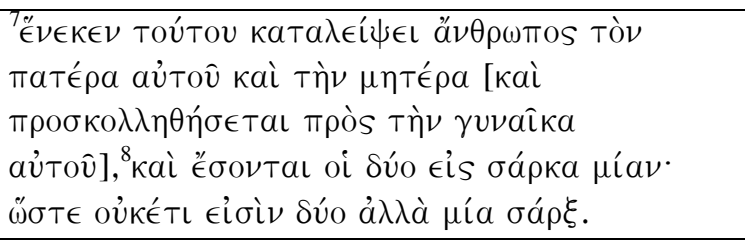 & 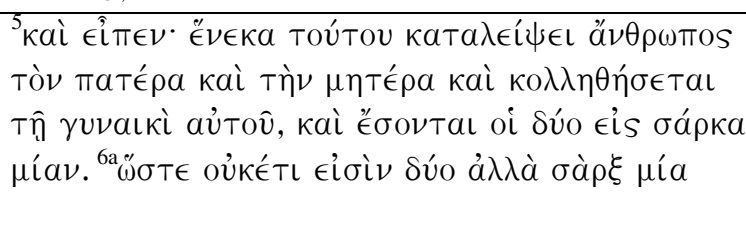 \\
\hline 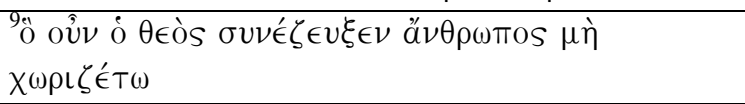 & 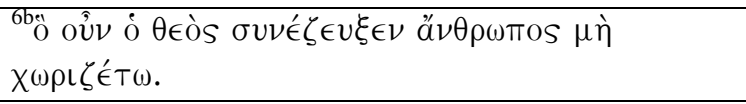 \\
\hline
\end{tabular}

\begin{tabular}{|c|c|c|c|}
\hline Lukas 16:18 & Matteus 5:32 & Markus 10:11-12 & Matteus 19:9 \\
\hline \multirow[t]{2}{*}{ 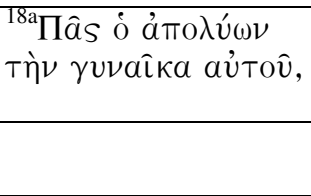 } & 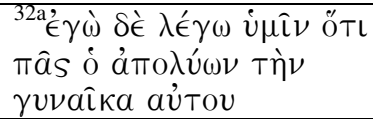 & 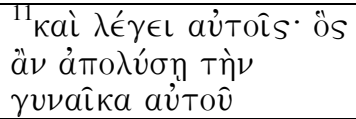 & 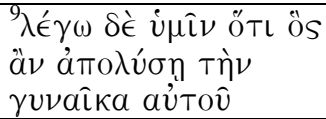 \\
\hline & 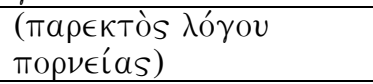 & & 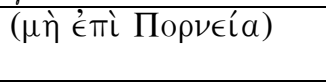 \\
\hline \multirow[t]{2}{*}{ 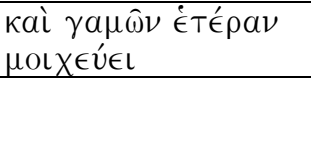 } & & 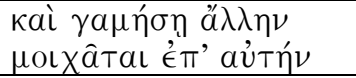 & 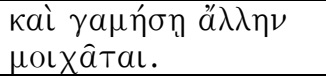 \\
\hline & 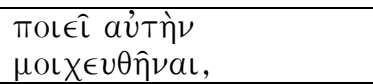 & & \\
\hline \multirow[t]{2}{*}{ 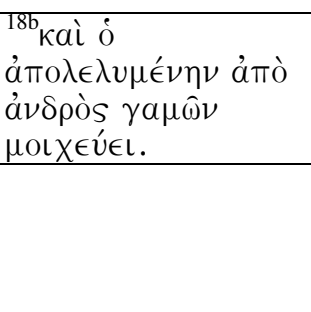 } & 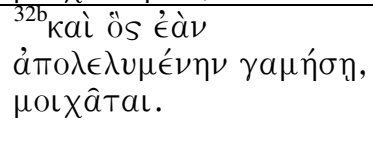 & & \\
\hline & & 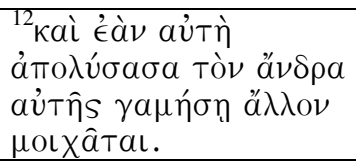 & \\
\hline
\end{tabular}

Jesus se uitspraak oor die huwelik val dus in twee dele uiteen: in Markus 10:5-9 en Matteus 19:4-6 en 8 handel Jesus oor dit wat as die "wese" van die huwelik beskou kan word, of anders gesê, sy beskouing van die huwelik as sosiale instelling. In die tweede deel van sy antwoord (Q 16:18, Mark 10:1112 en Matt 19:9) is die fokus meer spesifiek, te wete egskeiding, egbreuk, en hertrou. 


\subsubsection{Markus 10:5-9 en Matteus 19:4-6 en 8}

Markus 10:5-9 en parallel handel oor Jesus se antwoord op die vraag van die Fariseërs oor 'n aanvaarde gebruik in sy tyd, te wete dat 'n man, op grond van Deuteronomium 24:1, van sy vrou kan skei deur aan haar 'n skeibrief te gee. Jesus se reaksie op hierdie vraag is vyfledig van aard:

- Moses se bepaling is die gevolg van harde (onbekeerde) harte;

- hierdie bepaling bestaan nie van die begin van die skepping af nie (is nie God se wil nie);

- God het van die begin af man en vrou gemaak om bymekaar te wees;

- in die geval van 'n huwelik behoort 'n man sy vader en moeder te verlaat en saam met sy vrou lewe; en

- 'n man en vrou behoort nie twee te wees nie, maar een.

Jesus se antwoord op hierdie vraag behels meer as 'n net 'n reaksie op die vraag van die Fariseërs oor die interpretasie van Deuteronomium 24:1, en is in twee opsigte interessant: Eerstens stel Jesus in sy antwoord Genesis 1:27 en Genesis 2:24 aan die orde, te wete dat man en vrou is gemaak om bymekaar te wees, dat (in die geval van 'n huwelik) die man sy vader en moeder behoort te verlaat, en dat man en vrou een behoort te wees, nie twee nie. Die tweede interessantheid van Jesus se uitspraak is dat dit sterk ooreenkomste toon met van sy ander antwoorde in die evangelies op vrae van byvoorbeeld die Fariseërs of Sadduseërs ( $\mathrm{vgl}$ bv Mark 7:8, 13). Hieroor later meer in Afdeling 5.2.

Wat bedoel Jesus met hierdie uitspraak? Sê hy iets oor die huwelik, of nie? As Hy iets oor die huwelik sê, kondoneer Hy dit wat in terme van die kultuurbedding en sosiale konvensies van die eerste-eeuse Mediterreense onder die huwelik verstaan is, of nie? Bevat sy uitspraak ernstige kultuurkritiek? Sê dit iets oor die eerste-eeuse Mediterreense wêreld (en huwelik) as patriargaal gedrewe? Sê dit iets oor ander (eerste-eeuse) aanvaarbare eienskappe van die huwelik soos patrilokaliteit, die posisie van die vrou, die hiërargiese struktuur in die huwelik, poligamie en endogamie? Sê Jesus verder iets oor seksualiteit in die huwelik (die twee sal een word)?

Hierdie is myns insiens belangrike vrae wat aan die orde gestel moet word. Alleen deur die kritiese beantwoording daarvan sal geoordeel kan word of Jesus in bogenoemde uitspraak enigsins 'n standpunt oor die huwelik gehad het, en as Hy wel het, wat sy beoordeling van die huwelik as instelling was. 


\subsubsection{Lukas 16:18, Matteus 5:32, Markus 10:11-12 en Matteus 19:9}

Die tweede deel van Jesus se antwoord op die vraag van die Fariseërs handel oor egskeiding, egbreuk en hertrou. Anders as die eerste deel van Jesus se antwoord, is hierdie tweede deel - in terme van die identifisering van dit wat Jesus heel waarskynlik gesê het of nie gesê het nie - meer problematies, selfs enigmaties.

Volgens Lukas 16:18a en Markus 10:11 pleeg 'n man egbreuk wanneer hy van sy vrou skei en met ' $n$ ander vrou trou. Wanneer die voorwaardelike klousule in Matteus 19:9 ("behalwe oor owerspel" - bedoelende deur die vrou $^{5}$ ) nie in ag geneem word nie (deur dit as 'n Matteaanse invoeging te beskou), sou Matteus 19:9 dus met Lukas 16:18a en Markus 10:11 ooreenkom: 'n man wat skei en weer trou pleeg egbreuk. Indien die voorwaardelike klousule in Matteus 19:9 egter wel in ag geneem sou word, beteken Jesus se uitspraak in Matteus 19:9 dat 'n man wat van 'n vrou skei wat owerspel gepleeg het en dan weer trou, nie egbreuk pleeg nie. Lukas 16:18a; Markus 10:11 en Matteus 19:9 sal dan alleen met mekaar versoen kan word indien aanvaar sou word dat beide Lukas 16:18a en Markus 10:11 na 'n situasie verwys waarin die vrou nie owerspel gepleeg het nie. Indien dit egter nie die geval is nie, sou Jesus se uitspraak in Lukas 16:18a en Markus 10:11 nie met Matteus 19:9 versoen kon word nie. Lukas 16:18a en Markus 10:11 sou dan impliseer dat alle egskeiding wat op 'n hertroue uitloop egbreuk beteken, terwyl Matteus 19:9 sou impliseer dat alleen egskeiding en hertroue sonder owerspel egbreuk beteken, en egskeiding en hertroue na owerspel nie egbreuk nie. Watter een van hierdie twee moontlikhede Jesus bedoel het, is nie so eenvoudig uit Lukas 16:18a, Markus 10:11 en Matteus 19:9 afleibaar

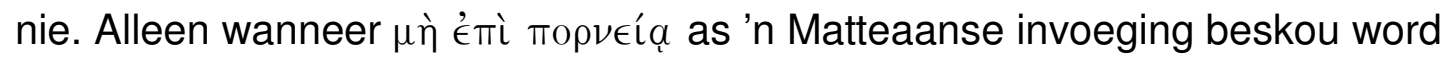
kan 'n oordeel gefel word, wat dan sou impliseer dat volgens Jesus alle egskeiding en hertroue egbreuk beteken.

Laasgenoemde afleiding roep ' $n$ tweede vraag na vore, te wete egbreuk teen wie? Wanneer daar in ag geneem word dat ' $n$ man in die eersteeeuse Mediterreense wêreld nie egbreuk teenoor sy vrou kon pleeg nie (kyk weer Van Eck 2007b:103-128), is die vraag teenoor wie die man, volgens Jesus, egbreuk sou pleeg inderdaad belangrik. Aangesien beide Lukas 16:18a en Matteus 19:9 nie die persoon teenoor wie egbreuk gepleeg word aandui nie, kan op grond van die verstaan van egbreuk in die eerste-eeuse Mediterreense wêreld (as die "steel van 'n man se besitting of eer"; kyk weer Van Eck 2007:103-128) aanvaar word dat die egbreuk óf teenoor sy (eerste) vrou se vader, óf teenoor die eerste man van die tweede vrou met wie hy na

\footnotetext{
${ }^{5}$ Die man in die eerste-eeuse Meditereense wêreld kon nie owerspel pleeg nie, dus is die verwysing hier na die vrou (kyk Van Eck 2007b:103-128).
} 
sy egskeiding getroud is, gepleeg word ${ }^{6}$. Markus 10:11 stel dit egter duidelik dat die egbreuk teen die man se eerste vrou gepleeg word (iets wat in die tyd van Jesus nie moontlik was in terme van die Mediterreense verstaan van die huwelik en die eer van die man nie).

Indien aanvaar sou word dat Jesus wel bedoel het dat egbreuk teenoor die vrou van die man gepleeg word, sal Jesus se uitspraak in Markus 10:11 alleen met Lukas 16:18a en Matteus 19:9 versoen kan word indien aanvaar word dat beide Lukas 16:18a en Matteus 19:9 ook die egbreuk wat gepleeg word sien as teenoor die vrou van die man. Lukas 16:18a en Matteus 19:9 sê dit egter nie, en dit is ' $n$ vraag of dit in hierdie twee tekste, in terme van die beskouing oor egbreuk in die eerste-eeuse Mediterreense wêreld, wel die bedoeling of 'n moontlikheid is. Die vraag is dus of hierdie drie tekste wel met mekaar versoen kan word. En as hulle nie kan nie, is die volgende vraag logies of daar bepaal kan word wat Jesus werklik oor egskeiding, egbreuk en hertrou gesê het?

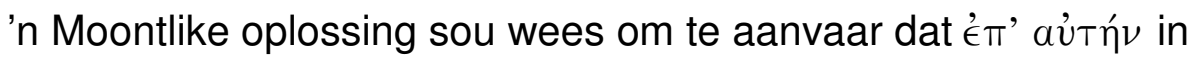
Markus 10:11 as 'n Markaanse byvoeging gesien moet word. Hierdie keuse sal beteken dat Lukas 16:18a, Matteus 19:9 en Markus 10:11 inderdaad met mekaar versoen kan word, behoudens die beslissing dat ook Matteus 19:9 se

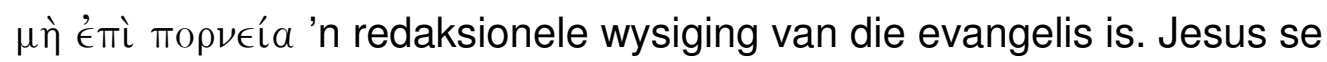
uitspraak ten opsigte van egskeiding, hertrou en egbreuk sal dan redelik maklik uit die drie genoemde tekste afleibaar wees: alle hertrou na egskeiding is egbreuk. Dit sou egter impliseer dat Jesus die vrou se posisie in die huwelik, so wel as die patriargale aard daarvan, kondoneer: die man pleeg egbreuk, maar nie teen sy vrou nie - hy steel alleen die besitting van die vader van sy eerste vrou, of die besitting van die man van sy tweede vrou.

Indien die ander roete gevolg word - deur '́ $\pi^{\prime}$ ' aữńv in Markus 10:11 nie as 'n Markaanse invoeging te sien nie - sou Markus 10:11 impliseer dat egskeiding gevolg deur hertrou egbreuk van 'n man teenoor sy eie vrou beteken. Die logiese implikasie van hierdie interpretasie sou wees dat Jesus nie sy tydgenote se verstaan van egbreuk en die minderwaardige posisie van die vrou in 'n patriargale huwelik gekondoneer het nie. Hierdie keuse los egter weer eens nie die problematiek rondom die Matteaanse voorwaardelike klousule op nie. Word $\mu \grave{\eta} \epsilon \epsilon \pi \grave{~ \pi o \rho \nu \epsilon i ́ a ~ i n ~ M a t t e u s ~ 19: 9 ~ a s ~ ' n ~ M a t t e a a n s e ~}$ invoeging gesien impliseer Markus 10:11 dat alle huwelike wat op egskeiding volg egbreuk teen die vrou in die huwelik beteken - al het die vrou owerspel gepleeg. Presies dit wat Matteus 19:9 nie impliseer nie.

Markus 10:12 bevat egter ook 'n verdere byvoeging wat nie in Lukas 16:18a en Matteus 19:9 voorkom nie, te wete dat ook 'n vrou wat van haar

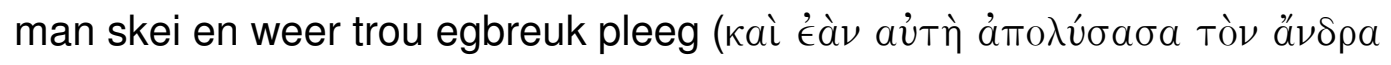

\footnotetext{
${ }^{6}$ Met ander woorde, teenoor die man in wie se eer die betrokke vrou ingebed is.
} 


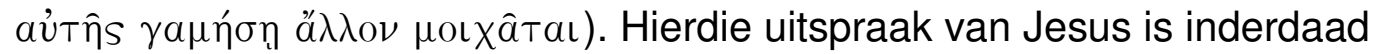
vreemd aan die eerste-eeuse Mediterreense verstaan van egskeiding, aangesien 'n vrou nie van haar man kon skei nie (kyk Van Eck 2007a:81-101). Indien Lukas 16:18a en Matteus 19:9 se stilswye in hierdie verband in ag geneem word, kan die vraag gevra word of Markus 10:12 'n Markaanse byvoeging is ten opsigte van Jesus se verstaan van die huwelik, egskeiding, egbreuk en hertrou. Op grond van Matteus 5:32a sou geargumenteer kon word dat Matteus wel in hierdie verband Markus 10:12 ondersteun, aangesien Jesus volgens Matteus 5:32 oordeel dat ' $n$ man wat van sy vrou skei en weer

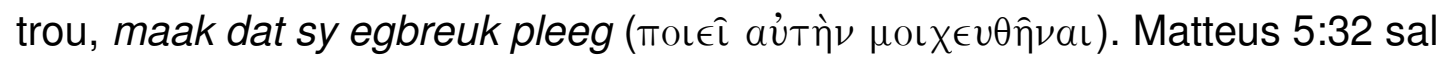
egter alleen as ondersteunend ten opsigte van Markus 10:12 beskou kon

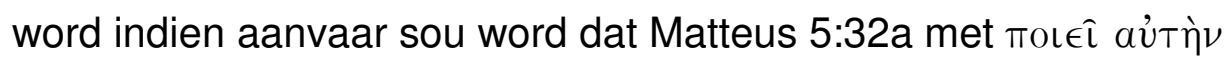
$\mu о \iota \chi \in \theta \hat{\eta} \nu a \iota$ impliseer dat die geskeide vrou weer trou. En indien dit wel die bedoeling van Matteus 5:32a is, sou die verdere implikasie wees dat die betrokke vrou, soos in die geval van Markus 10:12, egskeiding moes geïnisieer het.

Ten slotte enkele opmerkings oor Lukas 16:18b en Matteus 5:32b ( $Q$ 16:18b). Volgens $Q$ 16:18a pleeg 'n man wat met 'n geskeide vrou trou ook egbreuk. Ook hierdie uitspraak van Jesus is nie maklik om te verstaan nie. Verwys Jesus hier na 'n man wat nog nooit getroud was nie, of na 'n geskeide man? Indien Jesus na eersgenoemde verwys, is die vraag teenoor wie hy egbreuk pleeg? Is dit teenoor die vorige man van die vrou met wie hy trou? En as dit wel die geval is, hoe kan sy huwelik met 'n geskeide vrou egbreuk wees? Is dit omdat die vrou nie wettig van haar eerste man geskei is nie, of omdat haar vorige man na hulle egskeiding weer getrou het en so nie alleen egbreuk gepleeg het nie, maar in wese nog met haar getroud is omdat hertrou na egskeiding 'n betrokke egskeiding onwettig maak? Of verwys Jesus hier na 'n geskeide man wat weer trou? Teen wie pleeg hy egbreuk? Sy vorige vrou, sy vorige vrou se vader, of teen die vorige man van die vrou met wie hy nou getroud is (kyk ook Donahue \& Harrington 1992:295)?

\subsubsection{Opsommende opmerkings}

Wat het Jesus oor die huwelik, egbreuk, egskeiding en hertrou gesê? Uit bogenoemde bespreking is dit duidelik dat hierdie vraag nie so maklik beantwoordbaar is nie. Meer nog: as ons wel kan bepaal wat Jesus gesê het, wat het Jesus bedoel met wat Hy gesê het? Die beantwoording van hierdie twee vrae is van kardinale belang in 'n poging om te bepaal wat Jesus se houding oor die huwelik as instelling was, asook sy beskouing van egbreuk, egskeiding en hertrou.

In 'n poging om hierdie twee vrae te beantwoord word daar vervolgens eerste ingegaan op die mees resente navorsing wat aandag aan bogenoemde twee vrae skenk. 


\section{WAT SÊ ANDER HET JESUS GESÊ (EN BEDOEL)?}

\subsection{Raymond Collins}

Collins (1992:103) oordeel dat Markus 10:11 (en par) heel waarskynlik as 'n outentieke Jesus-logion beskou kan word. Beide Markus en Matteus het egter hierdie Jesus-logion op so 'n wyse redaksioneel in hulle evangelies opgeneem dat die oorspronklike bedoeling daarvan nie meer vasstelbaar is nie.

In die Markusevangelie is hierdie Jesus-logia (Mark 10:11) opgeneem in 'n groter literêre eenheid (Mark 10:1-12) - 'n redaksionele skepping van die Markusverteller - wat bestaan uit 'n inleiding (Mark 10:1), 'n konflikvertelling (Mark 10:2-10) en onderrig aan die dissipels (Mark 10:11-12). Volgens Collins (1992:102) is hierdie redaksionele skepping die produk van die kontekstuele wêreld van die Evangelie wat hy as Hellenisties-Joods (of dan HellenistiesChristelik) beskryf. Die doel daarvan formuleer hy soos volg: "Jesus' teaching on this Matter creates a social division between 'us', that is, Jesus and his disciples, and 'you', that is those who take issue with the Christian position, represented in the Markan narrative by the Pharisees, the traditional opponents of Christians and their way of life" (Collins 1992:102).

In hierdie konteks word Jesus se verbod op egskeiding deur Markus tweeledig begrond: Wat God saamgevoeg het mag geen mens skei nie (Mark 10:9), aangesien dit ' $n$ oortreding van die sesde gebod is (Mark 10:12). Met hierdie begronding, oordeel Collins, het Markus beide die Joodse en Hellenistiese komponent van sy geloofsgemeenskap aangespreek: vir die Jode word die verbod op egskeiding gegrond op die sesde gebod, en vir die Helleniste op die wil van God van die skepping af (Collins 1992:227). In Markus vind ons dus 'n "Christelike" standpunt ten opsigte van egskeiding, en nie die standpunt van Jesus nie. "In sum, Mark has created a new paradigm for the teaching of Jesus on divorce ... divorce [is] a deviation of God's creative will ... marital fidelity in monogamous marriage was to be a hallmark of the Christian way of life" (Collins 1992:228; kyk ook Donahue \& Harrington 2002:295).

Ook Matteus, volgens Collins (1992:229), het die oorspronklike Jesuslogion (Mark 10:11//Matt 19:9) "verchristelik" om dit sinvol te laat spreek in die kontekstuele wêreld van sy evangelie. Matteus 19:3-12 (waarin die oorspronklike Jesus-logion opgeneem is) is redaksionele verwerking van Markus 10:2-12, in die besonder die byvoeging van die "voorwaardelike klousule" in Matteus 19:9, en die weglating van '́ $\pi$ ' av่тฑ́ $\nu$ in Markus 10:11.

Collins (1992:143) oordeel dat genoemde byvoeging en weglating verklaar kan word teen die agtegrond van die feit dat in die eerste-eeu ' $n$ teks van die Dekaloog (los van die Pentateug) in sirkulasie was wat as basis vir alle rabbynse eksegese gedien het. Matteus was bewus van hierdie rabbynse 
eksegese aan die hand van die teks van die Dekaloog (vgl bv Matt 5:21-48; 15:19), en alhoewel Matteus 19:9 nie ' $n$ formele aanhaling uit die Pentateug is nie, verwys dit duidelik na die sesde gebod. Aangesien die sesde gebod nie

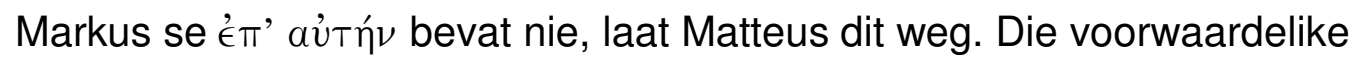
klousule, aan die ander kant, is 'n byvoeging analoog met Matteus 5:32, en dien as antwoord op die vraag van die Fariseërs in Matteus 19:3.

Die funksie van die byvoeging moet verstaan word in die lig van Matteus 5:17-20, Matteus se eis vir "oorvloediger geregtigheid": Jodechristene in die Matteaanse gemeente handel nie volgens Deuteronomium 24:1 nie, wel volgens die eis van 'n groter geregtigheid - daarom is egskeiding alleen moontlik na owerspel, en nie sommer vir enige rede (Deut 24:1) nie.

Wat ons dus in beide Markus 10:2-12 en Matteus 19:3-12 vind, aldus Collins (1992:103) is nie Jesus nie, maar die Jesus van die Nuwe Testament: "In all, the Jesus of the New Testament's literary tradition proclaims a counter cultural stance" (Collins 1992:103).

\subsection{David Instone-Brewer}

Instone-Brewer (2002:133-188) oordeel dat Lukas 16:18, Matteus 5:32 en Markus 10:2-10 (en par) Jesus se outentieke standpunt ten opsigte van die huwelik, egbreuk, egskeiding en hertrou bevat. Markus 10:2-10 en Matteus 19:3-12 is albei verwerkings van 'n oorspronklike vertelling wat nie meer bestaan nie, maar wel op grond van die weergawes daarvan in Markus 10:210 en Matteus 19:3-12 gekonstrueer kan word. Markus het die oorspronklike vertelling aangepas in die vorm van ' $n$ preek, en Matteus het dit ingeklee in die vorm van 'n Rabbiniese debat. Lukas 16:18 en Matteus 5:32, op hulle beurt weer, is twee verkorte weergawes wat die essensie van die twee langer vertellings in Markus en Matteus weergee. Die doel van hierdie verkorte weergawes was om die essensie van wat Jesus in hierdie verband gesê het makliker te kon onthou. Dus: al vier genoemde vertellings gaan terug na Jesus sonder enige weersprekings ten opsigte van mekaar.

Genoemde vertellinge bring ses sake na vore wat Jesus ten opsigte van die huwelik geleer het (Instone-Brewer 2002:177-178): die huwelik mag alleen monogamies wees, dit is 'n lewenslange verbintenis, egskeiding is nie verpligtend in die geval van owerspel nie, egskeiding is wel toelaatbaar wanneer daar op ' $n$ hardvogtige wyse met owerspel voortgegaan word, die huwelik is nie verpligtend nie en daarom is kinderloosheid nie ' $n$ rede vir egskeiding nie, en omdat egskeiding vir enige ander rede as aanhoudende (hardvogtige) egbreuk onaanvaar is, kom 'n huwelik (hertrou) na 'n egskeiding - vir enige ander rede as aanhoudende owerspel - op egbreuk neer. Hierdie konklusies word deur Instone-Brewer (2002:137-177) op die volgende argumente gebaseer: 
Jesus begrond die huwelik as monogamies deur in Markus 10:6-9 en Matteus 19:4-6 na Genesis 1:27 (God het hulle man en vrou gemaak) en Genesis 2:24 (die twee sal een word) te verwys wat, volgens Instone-Brewer (2002:134-136), die standaardtekste vir monogamie onder verskeie Joodse groepering was. Jesus se verwysing na Genesis 1:27 is veral van belang, aangesien dit in die Damaskus Dokument (CD 4:20-5:6) aan Genesis 7:9 (die diere het twee-twee, manlik en vroulik, in die ark ingegaan) verbind word. Volgens Jesus vind die huwelik dus tussen man en vrou (Gen 1:27) plaas, dit wil sê, twee mense (Gen 7:9), wat een word (Gen 2:24). Die feit dat Markus 10:6 Genesis 1:27 op presies dieselfde wyse as die Damaskus Dokument aanhaal, versterk die moontlike verband tussen Gen 1:27 en 7:9.

Jesus se verwysing na Genesis 1:27 en 2:24 dui egter nie alleen op die monogamiteit van die huwelik nie, maar ook op die lewenslange aard daarvan: God het nie alleen man en vrou gemaak nie (Gen 1:27 = Mark 10:6/Matt 19:4), Hy het hulle ook aanmekaar verbind (Gen 2:24 = Mark 10:8/Matt 19:5), en daarom mag niemand wat God bymekaargevoeg het, van mekaar skei nie ( $\chi \omega \rho \iota \zeta \omega$; Mark 10:9/Matt 19:6). Markus en Matteus se gebruik van $\chi \omega \rho \iota \zeta \omega$ is hier veral van belang: dit was nie alleen die standaardterm vir egskeiding in die tyd van Jesus nie, maar ook die anoniem van ámo $\lambda v \omega$ wat deur die Fariseërs in hulle inleidende vraag gebruik word (Mark 10:4/Matt 19:7).

Wat die reg tot egskeiding betref, is Instone-Brewer (2002:141-159) se

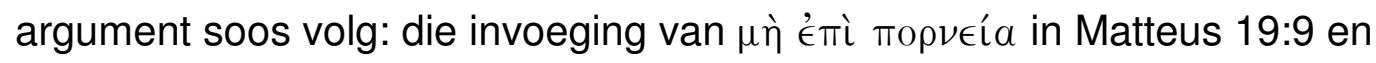

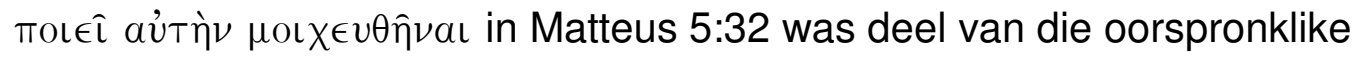
vertelling wat deur Matteus verwerk is, en die eerste-eeus leser sou dit as veronderstel beskou het in die lees van Markus 10:11 en Lukas 16:18. Vir Jesus was egskeiding dus wel toelaatbaar (in die geval van mopveía). Dit was egter nie verpligtend nie, wat afleibaar is uit die Fariseërs se gebruik van

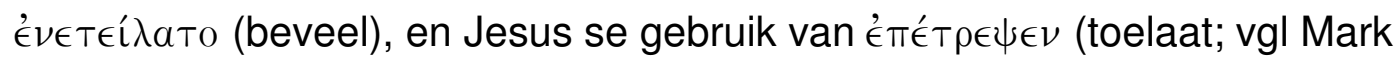
10:2-2/Matt 19:7-8).

Wanneer was dit toelaatbaar? Net in die geval van $\sigma \kappa \lambda \eta \rho о к а \rho \delta i ́ a v$ (Mark 10:5/Matt 19:8), dit wil sê, volhardende owerspel as die gevolg van 'n harde hart (Instone-Brewer 2002:146). Egskeiding was dus alleen toelaatbaar, nie as 'n bevel nie, omdat berou en 'n vergifnis na owerspel 'n moontlikheid was (Luk 17:3-4).

Egskeiding vir enige ander rede as volhardende owerspel het neergekom op 'n onwettige egskeiding (Instone-Brewer 2002:152). Dit is dan ook, volgens Instone-Brewer (2002:147-152), die agtergrond waarteen Markus 10:11/Matteus 19:9, Lukas 16:18 en Matteus 5:32 verstaan moet word: iemand wat met 'n ander vrou trou na 'n onwettige egskeiding pleeg egbreuk omdat so 'n persoon nie werklik geskei is nie en in werklikheid nog met sy eerste vrou getroud was. 
Ten slotte handel Instone-Brewer (2002:167-171) oor Matteus 19:12. Volgens hom verwys Matteus 19:12a na persone wat as eunugs gebore is, $12 \mathrm{~b}$ na persone wat eunugs geword het deur ontmanning, en 12c na persone wat 'n lewe van selibaat kies (Instone-Brewer 2002: 170). Dit beteken dus, volgens Instone-Brewer (2002:182), dat Jesus nie die "vermeerderingsopdrag" van Genesis 1:28 onderskryf het nie. Die implikasie hiervan is dat Jesus nie egskeiding op grond van kinderloosheid goedgekeur het nie.

\subsection{Bruce Malina en Richard Rohrbaugh}

Malina (1981:118-121), in die interpretasie van Jesus se uitsprake oor die huwelik, fokus daarop om Jesus se uitsprake oor die huwelik te interpreteer teen die agtergrond van die dominante kulturele konvensies van die eersteeeuse Mediterreense wêreld. Die huwelikstrategie in die tyd van die Nuwe Testament was defensief van aard, en die huwelik 'n reëling tussen twee families met die oog op die instandhouding of uitbreiding van bepaalde magsbelange (bv polities of ekonomies). Die huwelik was patriargaal, patrilokaal, hiërargies, poligamies en endogamies van aard. Egbreuk het neergekom op die "steel" van 'n ander man se besitting of eer - daarom kon die man nooit egbreuk teenoor sy vrou pleeg nie (alleen "buite" sy huwelik). Alleen die man kon egskeiding inisieer, en egskeiding het plaasgevind by wyse van die uitreiking van 'n skeibrief (Malina 1981:94-121).

Lukas 16:18 bevat Jesus se oorspronklike uitspraak ten opsigte van egbreuk, egskeiding en hertrou (Malina 1981:120), en moet om twee redes as 'n gelykenis gelees word. Die eerste is dat hierdie uitspraak van Jesus, wanneer daar gepoog word om dit letterlik te probeer verstaan, nie sin maak nie (Malina 1981:118). Tweedens vind Malina (1981:119-120) in Markus 10:212 en Matteus 19:3-12 'n bepaalde struktuur wat dikwels in Jesus se vertel van gelykenisse voorkom, te wete dat die (openbare) vertel van 'n gelykenis gevolg word deur 'n (private) verklaring van die betrokke gelykenis (vgl bv Mark 4:1-9 gevolg deur Mark 4:10-20; Mark 7:6-16 gevolg deur Mark 7:17-23; Matt 13:1-9 gevolg deur Matt 13:10-23; Matt 15:10-14 gevolg deur Matt 15:1520). ${ }^{7}$

In die verklaring van Lukas 16:18 (Mark 10:11//Matt 19:9) as gelykenis, oordeel Malina (1991:120-121), is Markus 10:8-9 (en par) van belang (dat God twee mense in die huwelik saamvoeg, dat twee so een word, en dat dit wat God saamgevoeg het niemand mag skei nie). Hierdie uitsprake toon aan dat Jesus die huwelik as 'n bloedverbintenis gesien het (dus nie as 'n wettige

\footnotetext{
${ }^{7}$ Malina (1981:119-120) se beskouing dat Lukas 16:18 (en par) as gelykenis verstaan moet word, is nie oortuigend nie. Matteus 19:3-12 voldoen wel aan die patroon gelykenis-private lering (Matt 19:3-9 gevolg deur Matt 19:10-12). In die geval van Markus 10:2-12 word die "gelykenis" van Matteus 19:9 egter as die verdere lering (Mark 10:10-12) aangebied. Wat dus in Matteus 19:3-9 as "gelykenis" aangebied word, dien in Markus 10:10-12 as verklaring van die gelykenis. In die geval van Lukas 16:18 word geen verklaring (private lering) aangebied nie.
} 
verbintenis nie). Soos die bloedverbintenis tussen vader en dogter nooit geskei kan word nie, so ook nie die twee partye in die huwelik nie. Egskeiding is dus nie moontlik nie, en daarom pleeg 'n man egbreuk wanneer hy skei en weer trou, aangesien die eerste huwelik in wese nie verbreek kan word nie. Interessant is dat Malina, in 'n latere werk saam met Richard Rohrbaugh (Malina \& Rohrbaugh 1993:120-122, 240-242), 'n ander standpunt blyk te handhaaf. Die huwelik word steeds as 'n bloedverbintenis beskou (Malina \& Rohrbaugh 1993:121), maar Lukas 16:18 (Mark 10:11//Matt 19:9) word nie gelees as 'n gelykenis nie. Inteendeel, dit moet letterlik verstaan word (kyk Malina \& Rohrbaugh 1993:121). Letterlik verstaan beteken Jesus se uitspraak dat dit wat verbied word nie egskeiding en hertrou is nie, maar egskeiding met die doel om weer te trou, aangesien dit op egbreuk neerkom (Malina \& Rohrbaugh 1993:121-122, 240-241).

Die verbod op egskeiding in die Tien Gebooie se bedoeling was, aldus Malina \& Rohrbaugh, om die moontlikheid van voortdurende konflik in die Israelitiese gemeenskap te beperk. Egbreuk het neergekom op die steel van ' $n$ ander man se besitting, die steel van sy eer. Eerbare optrede het beteken dat die man met wie se vrou egbreuk gepleeg is, moes reageer by wyse van wraak, wat gewoonlik gevolg is deur 'n bepaalde teenreaksie. Egbreuk het dus inherent die potensiaal van voortdurende konflik gehad. In die geval van egskeiding met die doel om weer te trou is die eer van die vader (en manlike familielede) van die vrou wat geskei word aangetas, wat tot bogenoemde konflik sou lei. Om dit te voorkom, beskou Jesus daarom egskeiding met die oog op hertrou as egbreuk.

Laasgenoemde is egter nie die geval wanneer egskeiding geskied op grond van "unchastity" (onkuisheid) nie (Matt 19:9). Volgens Malina \&

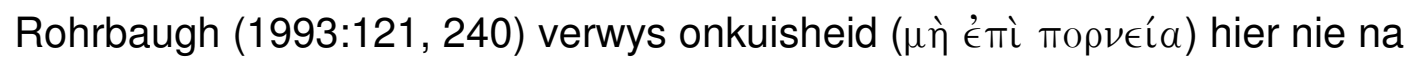
Deuteronomium 24:1 nie, maar wel na Levitikus 18:6-23 wat handel oor die verbod van geslagsgemeenskap met nabye familie (bv 'n seun met sy moeder of suster en 'n vader met sy kleindogter) of die vrou van 'n man wat jou naaste is.

Interessant, volgens Malina \& Rohrbaugh (1993:241), is dat Jesus egter niks sê oor egskeiding wat nie hertroue ten doel het nie. In wese kom hulle argument egter daarop neer dat egskeiding, aangesien die huwelik 'n verbintenis in terme van bloed is (soos vader en dogter), nie verbreek kon word nie.

\subsection{William (Bill) Loader}

Loader (2005:61-93, 238-241), op grond van sy eksegese van Q 16:18 (Luk 16:18//Matt 5:32) en Markus 10:2-12 (en par), oordeel dat die historiese Jesus in beginsel teen egskeiding was (Loader 2005:238). Hy begrond hierdie 
konklusie eksegeties soos volg: Markus 10:9//Matteus 19:6 ('n oorspronklike anekdoot/"one-liner" van die historiese Jesus wat "agter" Mark 10:2-9//Matt 19:3-9 lê, weerspieël duidelik Jesus se siening van die huwelik - wat God saamgevoeg ( $\sigma v \nu \epsilon^{\prime} \zeta \epsilon v \xi \in \nu$ ) het, mag geen mens skei $\left(\chi \omega \rho \iota \zeta \zeta^{\prime} T \omega\right)$ nie. Jesus se

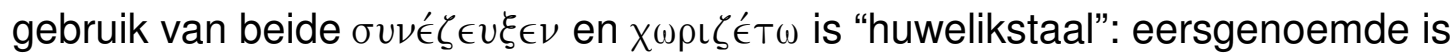
in die volksmond gebruik om na 'n huwelik te verwys, en laasgenoemde na egskeiding. Vir Jesus was die huwelik dus 'n bloedverwantskap (vgl Mark 10:8//Matt 19:6 - die twee sal een wees) wat nie tot 'n einde gebring kan word nie.

Wanneer Q 16:18 en Markus 10:2-12 (en par) teen hierdie agtergrond gelees word, is dit wat Jesus verbied nie egskeiding met die oog op hertrou nie, maar egskeiding in beginsel. Hertroue na egskeiding kan alleen egbreuk beteken indien die vorige huwelik nie ontbind is nie, en aangesien 'n huwelik nie ontbind kan word nie, impliseer 'n volgende huwelik egbreuk: "The sayings forbid divorce and remarriage by designating the latter as adultery. This assumes the original marriage has not been dissolved; otherwise the charge of adultery would not be valid" (Loader 2005:112).

Bo is reeds aangetoon dat in die eerste-eeuse Mediterreense wêreld die vrou, deur byvoorbeeld owerspel, teenoor haar man egbreuk kon pleeg. Die man kon nie egbreuk teenoor sy vrou pleeg nie, wel teenoor 'n ander man (in die geval van seksuele kontak tussen hom en die ander man se vrou). Ook in hierdie verband, oordeel Loader (2005:239), is Jesus se verstaan van egbreuk nuut, veral wanneer Markus 10:11 in ag geneem word: 'n man wat van sy vrou skei en weer trou pleeg egbreuk teen sy vrou.

'n Derde faset van Jesus se beskouing van egskeiding, wat volgens Loader (2005:24) as nuut getipeer kan word, hou verband met die sogenaamde "voorwaardelike klousule" in Matteus 5:32 en 19:9. Volgens Jesus gee Deuteronomium 24:1 nie aan die man die reg om van sy vrou te skei na owerspel nie, dit bied alleen die moontlikheid (wat in wese 'n onmoontlike moontlikheid is, aangesien geen mens kan skei wat God saamgevoeg het nie). As begronding vir hierdie interpretasie van Matteus 5:32 en 19:9 lê Loader (2005:239) klem op die woordkeuse van enersyds die

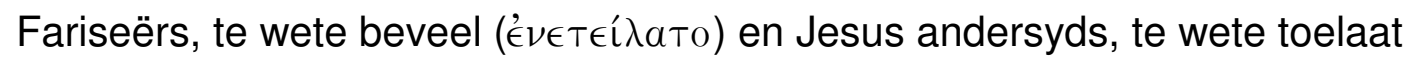

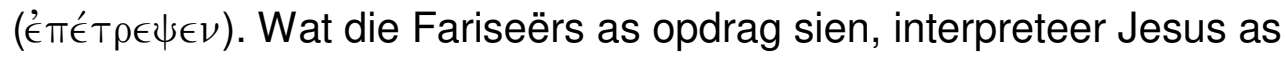
moontlikheid. Harde harte maak hierdie moontlikheid, volgens Jesus, 'n bevel. Dit is egter nie, aldus Loader (2005:239), wat God verwag nie: "As with the instruction about swearing oaths in the Sermon on the Mount, the true follower of God's ways should not make use of the divorce provision". 
Loader (2004) is verder van oordeel dat Jesus se streng beskouing ten opsigte van egskeiding, egbreuk en hertrou 'n duidelike invloed op die LXX se vertaling van onder andere Eksodus 20:2-17 en Deuteronomium 5:6-21 gehad het. Waar Eksodus 20:13-15//Deuteronomium 5:17-19 die volgorde doodslaan, egbreuk en steel het (i t v die sesde, sewende en agste gebod), daar lees die LXX egbreuk, steel en moord. ${ }^{8}$ So word die verbod op egbreuk die eerste gebod in terme van die tweede tafel van die wet, duidelik 'n posisie van belangrikheid. Dieselfde klem ten opsigte van die begeer van die vrou van 'n ander man is ook uit die LXX afleibaar: waar Eksodus 20:17 die begeer van die huis van 'n naaste voor die begeerte na sy vrou plaas, daar is die volgorde in die LXX eers die begeerte na die vrou en dan na die huis van 'n ander man. Deuteronomium 5:21 weer het wel die volgorde vrou en dan huis, maar die LXX het bewustelik die begeerte na vrou, huis, land, dienskneg, diensmaagd, os of esel as aparte gebooie vertaal. Ook Markus 7:21, Lukas 18:20-21, Romeine 13:9 en Jakobus 2:11 toon die invloed van die volgorde egbreukmoord-steel in die LXX. Volgens Loader (2004:25) is die vertaling van die LXX, asook die invloed wat dit op sekere tekste in die Nuwe Testament het, 'n aanduiding van die streng standpunt wat Jesus ten opsigte van veral egbreuk ingeneem het. In die woorde van Loader $(2004: 117,118)$ : "This may be an innovation of the Septuagint perhaps reflecting greater concern with adultery and related matters ... in the first century CE".

Ten slotte vind Loader (2004:119-124) ook in die LXX se vertaling van onder andere Genesis 1:27, Genesis 2:24 en Deuteronomium 24:1 grond vir Jesus se beskouing van die huwelik as monogame en 'n lewenslange bloedverbintenis.

\subsection{Opsommende opmerkings: Wat het Jesus gesê en bedoel?}

Uit bogenoemde bespreking van die vier mees resente navorsers oor Jesus en die huwelik is dit duidelik dat daar nie alleen verskil bestaan ten opsigte van die identifisering van die outentieke Jesus-logia rakende die huwelik nie, maar ook wat betref die betekenis (bedoeling) daarvan.

\footnotetext{
${ }^{8}$ Loader (2004:2), in sy analise van Eksodus 20:2-17 en Deuteronomium 5:6-21 (waar hy as teks die Biblia Hebraica Stuttgartensia van Elliger \& Rudolph [1983] gebruik), maak gebruik van die eklektiese LXX-uitgawe van Göttingen (Septuaginta. Vetus Testamentum Graecum). Steyn (1996:451-458) toon egter by implikasie aan dat Loader, indien hy van Kodeks Aleksandrinus (LXX) of Kodeks Vaticanus (LXX) gebruik gemaak het, hy nie tot dieselfde gevolgtrekkings sou kon kom nie. Die volgorde van Eksodus 20:13-15 en Deuteronomium 5:17-20 in Kodeks Aleksandrinus (LXX) is byvoorbeeld doodslaan, egbreuk, steel en valse getuienis, en dié van Kodeks Vaticanus (LXX) weer egbreuk, steel, doodslaan en valse getuienis. Behalwe dat hierdie twee Kodekse se orde ten opsigte van Eksodus 20:13-15 en Deuteronomium 5:17-20 van mekaar verskil, plaas beide die Kodekse egbreuk nie bo aan die Iysie nie ( $\mathrm{d}$ w s, as die sesde gebod en by implikasie die eerste gebod van die tweede tafel nie).
} 
Volgens Instone-Brewer gaan Jesus se uitsprake ten opsigte van die huwelik, egbreuk, egskeiding en hertrou terug na 'n tradisie wat nie meer bestaan nie, deur Markus 10:2-10 en Matteus 19:3-12 verwerk is, en in Lukas 16:18 en Matteus 5:32 tot die essensiële daarvan verkort is. Volgens hierdie verwerkings en verkortings het Jesus die huwelik as 'n monogame en lewenslange verbintenis gesien, en egskeiding alleen as 'n moontlikheid na hardvogtige owerspel (alhoewel nie verpligtend nie). Egskeiding om enige ander rede het op "onwettige" egskeiding neergekom, met die implikasie van egbreuk in die geval van hertroue.

Collins is meer beskeie in sy poging om die uitsprake van Jesus rakende die huwelik te verstaan. Hy oordeel dat Markus 10:11 (en par) heel waarskynlik as 'n outentieke Jesus-logion beskou kan word, maar so deur Markus en Matteus redaksioneel in hulle evangelies verwerk is dat die oorspronklike bedoeling daarvan nie meer vasstelbaar is nie - al wat ons wel kan bepaal is dit wat die Nuwe-Testamentiese Jesus se beskouing van die huwelik was.

Malina weer oordeel dat Lukas 16:18 'n oorspronklike Jesus-logion ten opsigte van die huwelik bevat, en as 'n 'n gelykenis gelees behoort te word. Sy interpretasie van hierdie gelykenis kom daarop neer dat Jesus die huwelik as 'n bloedverbintenis gesien het, dus 'n verbintenis wat nie verbreek kan word nie. Egskeiding was dus nie 'n moontlikheid nie, en daarom het alle tweede huwelike op egbreuk neergekom. In 'n latere werk saam met Rohrbaugh wil dit egter lyk of Malina nie meer bogenoemde standpunt handhaaf nie: die huwelik word steeds as 'n bloedverbintenis beskou, maar Lukas 16:18 moet nie as 'n gelykenis van Jesus gelees word nie. Lukas 16:18 sou dan beteken dat wat Jesus afwys nie egskeiding en hertrou is nie, maar egskeiding met die doel om weer te trou, aangesien dit op egbreuk neerkom en sou lei tot voortdurende konflik tussen die betrokke families.

Loader, ten slotte, identifiseer Q 16:18 en Markus 10:2-12 (en par) as outentieke Jesus-logia ten opsigte van die huwelik. Hierdie logia toon syns insiens aan dat Jesus in beginsel teen egskeiding was. Omdat God twee mense in die huwelik saamvoeg, is die huwelik ' $n$ bloedverbintenis wat nie tot 'n einde gebring kan word nie, en daarom kom alle tweede huwelike op egbreuk neer. Jesus se uitsprake ten opsigte van die verstaan van die huwelik in sy tyd was in verskeie opsigte nuut: 'n man kon egbreuk teenoor sy eie vrou pleeg, en Deuteronomium 24:1 het alleen die moontlikheid van egskeiding daargestel, en nie die reg daartoe nie. 


\section{JESUS EN DIE FAMILIE IN DIE EERSTE-EEUSE MEDITERREENSE WÊRELD}

Bogenoemde opsomming van die mees resente navorsing oor Jesus en die huwelik toon aan dat daar nie eenstemmigheid bestaan oor dit wat Jesus oor die huwelik sou gesê het en, indien bepaal sou kon word wat Jesus gesê het, wat sy bedoeling daarmee was nie. Myns insiens sou daar miskien meer klarigheid oor bogenoemde twee sake verkry kon word indien erns gemaak word met die insig dat die huwelik in die eerste-eeuse Mediterreense wêreld in die familiale instelling ingebed was, dit wil sê, 'n produk van die sosiale instelling van die familie was, in diens van die familie gestaan het, en altyd ondergeskik aan die belange van die familie gefunksioneer het (kyk Malina 1981:94-95, Malina \& Rohrbaugh 1992:29 in Van Eck 2007a:81-101).

Uitgaande van hierdie insig word die tese aangebied dat Jesus se beskouing van die huwelik nie losgemaak kan word van sy beskouing van die familie nie. As deel van die beredenering van hierdie tese word daar nou kortliks ingegaan op 'n beskrywing van Jesus se beskouing van die familiale instelling van sy tyd. Hierdie beskrywing is funksioneel van aard in twee opsigte, te wete dat daar geoordeel word dat Jesus se beskouing van die familie van hulp kan wees in enersyds die identifisering van outentieke Jesuslogia rakende die huwelik, en andersyds 'n meer presiese beskrywing van Jesus se beskouing of evaluering van die huwelik as instelling in sy tyd moontlik kan maak. Met ander woorde, dit kan dalk antwoorde verskaf op die twee wat herhaaldelik hierbo gestel is: wat het Jesus oor die huwelik gesê, en wat het Hy daarmee bedoel?

\subsection{Wat het Jesus oor die familie gesê?}

In terme van onder andere die kriteria van onafhanklike, meerdere vroeë betuiging, onderskeidende kenmerke, verleentheid, onvergeetlikheid en koherensie (kyk o a Funk et al 1993:19-33; Theissen \& Hertz 1998; Tatum 1999:102-107; Van Aarde 2005:23-26; Wallace 2006:68-69) gee die volgende vier Jesus-logia waarskynlik Jesus se houding ten opsigte van die familie in die eerste-eeuse Mediterreense wêreld weer (kyk o a Crossan 1991:427-450; Kloppenborg 1988; Funk 1990; Funk et al 1993; Horsley 1993:233-240; Robinson, Hoffmann \& Kloppenborg 2000; Guijarro 2004:114):

- Evangelie van Tomas 55:1-2, 101:1; Q 14:26-27 (Luk 14:26-27//Matt 10:37-38): die volg van Jesus impliseer haat teenoor die eie familie. Op grond van die beginsel van koherensie kan die saaklike inhoud van die volgende uitsprake van Jesus (alhoewel heel waarskynlik nie outentieke Jesus-logia nie) as ondersteuning dien vir bogenoemde uitspraak as outentieke Jesus-logion: Markus 1:16-20//Matteus 4:18-22//Lukas 5:1-11 
(die roeping van die dissipels wat hulle families agterlaat); Markus 10:2930//Lukas 18:29-30//Matteus 19:28-29 (niemand het 'n huis, broer of suster, vader of moeder, vrou of kind ter wille van Jesus verlaat en is nie daarvoor beloon nie); Markus 8:34//Lukas 9:23//Matt 16:24 (as iemand Jesus wil volg moet hy/sy bereid wees om die kruis op te neem en te volg); en Markus 6:1-6/Matteus 13:53-56 ('n profeet word nie deur sy eie familie gerespekteer nie).

- Evangelie van Thomas 99:1-3; Markus 3:32-35//Lukas 8:20-21//Matteus 12:47-50: Jesus se familie is nie sy moeder en broers nie, maar hulle wat die wil van die Vader doen. Belangrik van hierdie logion is die afwesigheid van enige verwysing na die vader (kyk Horsley 1993:238).

- Evangelie van Tomas 16:1-4; Q 12:51 (Luk 12:51-53//Matt 10:34-36): Jesus het nie gekom om vrede te bring nie, maar om families te verdeel. Vergelyk ook die Evangelie van Thomas 49:1 en 75 in hierdie verband: slegs hulle wat "alleen" is, sal gekies word.

- Evangelie van Thomas 86; Q 9:57-60 (Luk 9:57-60//Matt 8:18-22): Jesus het geen vaste woonplek nie, en vir diegene wat Jesus volg is daar nie tyd om eers 'n vader te begrawe en Jesus dan te volg nie.

Bogenoemde Jesus-logia ${ }^{9}$ toon 'n duidelik anti-familiale tendens, ${ }^{10}$ en word deur navorsers op een van twee wyses geïnterpreteer. Theissen (1989:343360; Theissen \& Mertz 1998:186-190), as voorbeeld, is van oordeel dat

\footnotetext{
${ }^{9}$ Horsley (1993:242) is van oordeel dat Q 14:11 (Lukas 14:11; 18:14//Matt 23:12), te wete wie eerste is sal laaste wees, en wie laaste eerste, ook as 'n anti-patriargale Jesus-logion beskou kan word. Die gebruik van Q 14:11 deur Matteus 23:12 is in hierdie verband belangrik, aangesien dit in Matteus aangebied word as deel van Matteus 23:8-12 waarin Jesus sy dissipels vra om niemand vader te noem behalwe hulle Vader in die hemel nie.

${ }^{10}$ Guijarro (2004:114-15), Lang (1990:281) en Hellerman (2001:67) is van oordeel dat verskeie tradisies in die Evangelies op die teendeel dui, te wete dat Jesus ook positiewe uitsprake oor die familie as instelling gemaak het. Die volgende voorbeelde word genoem: in Markus 7:6-13 ondersteun Jesus die oortuiging dat kinders aan hulle ouers gehoorsaam moet wees, Markus 10:2-12 evalueer die huwelik as instelling positief, Markus 3:31-35 en 10:28-30 gebruik die beeld van die familie as analogie vir dissipelskap, Jesus gee aan die dissipels die opdrag om die evangelie aan huishoudings te gaan verkondig (Mark 6:10: 10:5-7), en die dissipels word soms deur families gehuisves (Mark 11:11; 14:3; kyk Guijarro 2004:114-115). Jesus se viering van die paasmaaltyd - wat in wese 'n familiefees was - dui ook op sy positiewe waardering van die familie (Lang 1990:281; Hellerman 2001:67; Countryman 1988:173). Die vraag is egter of genoemde tradisies na Jesus teruggevoer kan word, en of hierdie tradisies nie ' $n$ weerspieëling van die vroeë na-Pase Jesusbeweging(s) is nie. Malina (1999:30-32) is byvoorbeeld van oordeel dat Jesus se uitsprake waarin daar na die Jesusvolgelinge verwys word in terme van 'n fiktiewe (surrogaat) familie 'n na-Pase situasie reflekteer.
} 
bogenoemde Jesus-logia alleen betrekking op Jesus se onmiddelike dissipels gehad het. In die vroeë Jesusbeweging was daar twee soorte dissipels, te wete die rondreisende charismate (op wie bg logia van toepassing was), en ander volgelinge van Jesus wat tuis gebly het en aan die reisende charismate ondersteuning en huisvesting verskaf het. Jesus het dus nie 'n anti-familiale beskouing gehad nie, aangesien bogenoemde logia slegs van toepassing op 'n paar van sy volgelinge was en dus geen impak of die familie as instelling gehad het nie. Theissen \& Mertz (1998:188-190) oordeel verder dat Jesus dikwels na sy volgelinge as 'n fiktiewe familie verwys het na analogie van die eerste-eeuse familiale instelling (bv Mark 3:31-35; 10:28-30; Matt 23:9), maar met een besliste uitsondering: hierdie fiktiewe familie het geen plek vir die vader - die patriargale simbool van gesag - gehad nie: die dissipels was deel van 'n nuwe familie waarvan die vader God was (kyk ook Schüssler Fiorenza 1992:151-154).

Navorsers soos Horsley (1993:231-245 ${ }^{11}$ ), Schüssler Fiorenza (1992:151-154) en Van Aarde (2001a:77) is egter van mening dat bogenoemde Jesus-logia nie net van toepassing op sekere van Jesus se volgelinge was nie. Jesus het 'n besliste anti-familiale beskouing gehad ten opsigte van die patriargale familie as instelling (kyk ook Countryman 1988:168-173, 181; Meier 1991:316-317; Loader 2005:142; Osiek 2006:838842). Ook Crossan (1991:299-301) handhaaf hierdie oortuiging. Volgens Jesus was sy familie nie die moeder wat Hom in die lewe gebring het (EvTom 79:1-2) of sy moeder en broers wat buite vir Hom staan en wag nie (EvTom 99:1; Mark 3:32-35 en par), maar hulle wat die wil van sy Vader doen. Jesus het Homself verder skerp teenoor hiërargie as aanvaarde gesagsnorm in die familie uitgespreek (EvTom 16:1-4; Q 12:51), en Jesus se uitspraak oor die haat van die eie familie (EvTom 55:1-2, 101:1; Q 14:26-27) laat geen twyfel oor wat Jesus se standpunt ten opsigte van die familie was nie. Daarom ook dat Jesus, aldus Crossan (1991:300-301), weier om betrokke te raak by 'n dispuut tussen twee broers oor hulle vader se erflating (EvTom 72:1-3; Luk 12:13-15).

Die essensie van die patriargale familie in die tyd van Jesus kan soos volg beskryf word:

[l]n ... a ... culture, where the principal symbolization of social relations was in terms of kinship (bv die eerste-eeuse Mediterreense

\footnotetext{
${ }^{11}$ Horsley (1993:231) formuleer die fokus van Jesus se bediening soos volg: "Many important teachings of Jesus clearly concern local community relations, yet there is no reason to believe that they pertained only or primarily to the inner group of the disciples or to the earliest postresurrection community in Jerusalem. The only realistic concrete alternative would appear to be local (town or village) communities, where the ministry of Jesus and his disciples were focused".
} 
wêreld - EvE) the social structure was patriarchal. The father was the head of the family, in no uncertain terms; ... in such traditional patriarchal societies ... wives and children ... are treated as the property of the male head of the household. ${ }^{12}$

(Horsley 1993:232)

Die status van die man as hoof van die familie was gebaseer op die oortuiging dat lewe in manlike saad geleë was: "the female provided nothing beyond a place for the seed's growth until birth" (Malina-Jacobs 1993:1). Die gevolg van hierdie beskouing oor voortplanting (prokreasie) was 'n samelewing waarin die man as die vrou se meerdere beskou is. Hierdie meerdere posisie van die man was uitgedruk deur die kernwaarde van die eerste-eeuse Mediterreense wêreld, te wete eer. Die posisie van die vrou, daarenteen, was gesimboliseer deur skande.

\begin{abstract}
Unlike the male whose gender made him whole and complete, the female was raised with a sense of shame which made her as dependent on the male for her own "completeness" as she was dependent on him for children, support and honor. The woman whose modesty and strictly controlled behavior in public manifested this sense of shame brought honor on the males to whom she was attached.
\end{abstract}

(Malina-Jacobs 1993:1)

Vrouens en kinders was dus die patriarg se mindere, sy besittings. Die patriargale verhouding tussen man en vrou is selfs gesien as analoog vir die verstaan van God se skeppingsorde: "God is to man as man is to woman; man is to nature what man is to woman; the master is to slave as man is to woman, the emperor is to his people as man is to woman, the teacher is to his pupil as man is to woman" (Malina-Jacobs 1993:2).

\title{
4.2 Jesus: Anti-familiaal en anti-patriargaal
}

Volgens Jesus het die familie as androsentriese/patriargale/hiërargiese instelling vroue, kinders en nie-dominante mans (die met min of sonder eer) gemarginaliseer, gedomineer en gesubordineer (Kloppenborg 1990:196). In kort: die familie as patriargale instelling het persone (legitieme) slagoffers van 'n gelegitimeerde institusionele patriargale instelling gemaak (Crossan 1991:302; kyk ook Pilch 1993:101-113; Osiek 2006:832-835). In die woorde van Loader (2005:142): “Jesus' radical sayings about family are more

\footnotetext{
${ }^{12}$ Kyk ook Van Aarde (2000:226): "Mediterranean family life was patriarcichally oriented, with the father the most important figure within the first-century family. The male head of the family enjoyed absolute authority over his wife(s), children, slaves and other dependants".
} 
subversive than is usually recognized ... it is a challenge to the (patriarchal EvE) household system which underpinned social structure in the ancient world [as] basis for the systems of control, economy, production and patronage".

Die onderhawige bestek maak dit ontmoontlik om Jesus se subversering van die partriargale eerste-eeuse Mediterreense wêreld in detail beskryf. In wat volg word breë lyne getrek wat myns insiens volledig genoeg aantoon dat Jesus anti-patriargaal ingestel was. Aandag word aan drie sake gegee wat direk met die familie verband hou, te wete Jesus se houding teenoor vroue en kinders, asook Jesus se genesings.

\subsubsection{Vroue}

Jesus het met vroue as gemarginaliseerdes in 'n patriargale samelewing geassosieer: ${ }^{13}$ vroue was deel van Jesus se volgelinge (Mark 15:40-41; Luk $8: 1-13 ; 10: 38)^{14}$ en verskeie vroue is deur Jesus genees (Mark 5:21-43; 7:2430; Luk 7:11-17; 8:1-3; 13:10-17). Jesus het nie onderskeid tussen man en vrou in terme van geslag gemaak, of vroue as seksuele objekte of simbole van onreinheid gesien nie (Mark 7:24-30). Ook het Jesus respek vir die vrou se seksualiteit geopenbaar (Matt 5:28). Vroue word verder deur Jesus dikwels as voorbeelde van ware geloof en dissipelskap voorgehou (Mark 7:24-30; 14:41-44), Hy laat 'n vrou toe om Hom te salf (Mark 14:3-9), praat met 'n vrou by 'n put (Joh 4:1-20), eet waar prostitute teenwoordig is (Luk 7:34-50), en vroue is dikwels deel van sy gelykenisse (Matt 13:31-33//Luk 15:4-1015). Jesus se geslagsregister sluit die name van vroue met bedenklike reputasies

\footnotetext{
${ }^{13}$ Corley (2002a; 2002b:137-160) is nie oortuig dat Jesus 'n subversiewe houding ten opsigte van vroue gehad het nie. Corley onderskei egter nie op 'n histories-kritiese wyse noukeurig genoeg tussen die nie-androsentriese historiese Jesus en die androsentriese perspektiewe van die onderskeie evangeliste nie. Dreyer (2002:1679-1706) het oortuigend aangetoon dat Jesus se nie-androsentriese houding ten opsigte van vroue aantoonbare "vervreemding" in die Evangelies ondergaan het. Markus teken vroue oorwegend positief (Tolbert 1998:350362), maar eindig egter sy evangelie met die vroue wat die graf weghardloop (Dreyer 2002:1680-1687), Matteus teken vroue nie as gelyke deelnemers in die geloofsgemeenskap nie (Dreyer 2002:1687-1692), en Lukas is allesbehalwe "vroue-vriendelik" (Dreyer 2002:1698; kyk ook Schaberg 1998:363; Karris 2002:23-43; Dreyer 2007).

${ }^{14}$ Die volg van Jesus deur vroue-dissipels was ' $n$ besondere sterk subversiewe handeling in terme van die sosiale waardes van die eerste-eeuse Mediterreense wêreld - beide Jesus se aanmoediging daarvan en vroue wat hulle dit laat welgeval (veral Maria Magdalena; vgl Howes \& Van Aarde 2005a:319-322) Horsley (2003:304) maak in hierdie verband die volgende opmerking: "[l]t seems clear (in Mark - EvE) that the implicit paradigm of leadership is the service role of woman in the patriarchal family, now being held up against the male disciples who represent the imperial model of exploitative power and privilege" (kyk ook Howes \& Van Aarde 2005b:1205-1207; Schüssler Fiorenza 1979, 1980, 1982).

${ }^{15}$ Vergelyk in hierdie verband dat in die eerste gelykenis (Luk 15:4-7; die gelykenis van die verlore skaap) 'n man as die een wat soek aangebied word, en in die tweede gelykenis (Luk 15:8-10) 'n vrou hierdie rol vervul. Beide gelykenisse se uitkoms word ook dieselfde beskryf.
} 
in (Matt 1:1-17, Luk 3:21-38), Hy weier om op 'n seksistiese wyse tussen die twee geslagte te onderskei (EvTom 22:3-4), en weier ook om betrek te word by androsentriese humor oor 'n vrou wat met 'n sewende man getroud is (Mark 12:18-27; kyk o a Loader 2005:18, 44, 57-58, Bultmann 1988:13; Van Aarde 2001a:135; Crossan 1991:267, 302; Johnson-Debaufre 2005:43-80). Jesus se inklusiewe, nie-seksistiese en gelykwaardige hantering van die vrou was dus duidelike kritiek op 'n patriargale samelewing wat die vrou seksisties uitgesluit en gemarginaliseer het. ${ }^{16}$

\subsubsection{Kinders}

In die eerste-eeuse patriargale samelewing is kinders as "nobodies" gereken (Crossan 1991:266-269). Kinders was die mees kwesbare persone in die eerste-eeuse Mediterreense samelewing, en is altyd eerste geraak deur droogtes, oorlog, siekte en verskuiwing. 'n Kind het geen status in die patriargale familie gehad nie, dit wil sê, hulle status was gelyk aan die van slawe wat deel was van dieselfde huishouding. Weeskinders is as stereotipe gebruik om na die swakste en kwesbaarste persone in die samelewing te verwys, en om na 'n volwasse persoon as 'n kind te verwys is as 'n belediging beskou (vgl Matt 11:16; kyk Malina \& Rohrbaugh 1992:117-118).

Teen hierdie agtergrond kan Jesus se beskouing van en optrede teenoor kinders nie anders as kritiek op die patriargale samelewing van sy tyd beskou word nie. Vir Jesus kon alleen hulle wat soos kinders word deel wees van die koninkryk van God (EvTom 22:2; Mark 9:33-37 en Markus 10:15//Lukas 18:17//Matteus 18:1-4). Aangesien kinders geen status of eer gehad het nie, was hierdie uitspraak van Jesus niks anders as kritiek op 'n patriargale samelewing waarin eer en status alles was nie (Crossan 1991:269). In die woorde van Countryman (1988:188): "By making the child and not the father the model for entry into the reign of God, Jesus again negated the family structures of the society and reversed the hierarchical assumptions that governed all life".

Jesus assosieer selfs met straatkinders, en bied hulle aan as juis diegene wat deel van die koninkryk is (Van Aarde 2001a:135-154; 2004:132136). As "nobodies" is kinders in terme van die sosiale stratigrafie van die eerste-eeuse wêreld as deel van die "expendables" gesien. Lees laasgenoemde letterlik. Kinders is om verskeie redes weggegooi, wat dikwels daartoe gelei het dat hulle seksueel (bv by wyse van prostitusie) misbruik is

\footnotetext{
${ }^{16}$ Alhoewel die tekste hierbo genoem heel waarskynlik nie in elke geval na die historiese Jesus teruggevoer kan word nie (vgl Crossan 1991:427-450; Funk et al 1993; Robinson et al 2000) word aanvaar dat hierdie tekste ten minste saaklik in kontinuïteit staan met die historiese Jesus se nie-androsentriese houding teenoor vroue. Alhoewel daar beslis "vervreemding" in die Evangelies ingetree het ten opsigte van Jesus se houding teenoor die vrou (kyk weer voetnoot 13), beteken dit egter nie dat die Evangelies tog die "saak" van Jesus in hierdie verband weergee nie, veral wat die "Jesus-dade" betref.
} 
(kyk Van Aarde 2001a:146; 2004:134). In die lig hiervan, oordeel Loader (2005:20-24), kan Jesus se woorde in Markus 9:42-48//Matteus 18:6-9 gesien word as ernstige kritiek teen pederastie (kyk ook Brooten 1996:175-186). Pederastie was, in hierdie konteks, die indirekte gevolg van die posisie van die kind in 'n patriargale samelewing, en Jesus se kritiek op pederastie was dus kritiek op die patriargale familie as instelling.

\subsubsection{Genesings en eksorsismes}

Kultureel-antropologiese studies het oortuigend die verband tussen duiwelsbesetenheid/geestesiektes en sosiale spanning of konflik aangetoon (Theissen 1983:249; Pfohl 1985:38-40; Sanders 1993:133-135, Davies 1995:81-111; Van Aarde 2000; 223-236; 2001a:146; Guijarro 2002:164-167).

In the world of Jesus were two social domains: the public (political) and private (familial), and in both were people under constraints of abusive authority. In the kinship context, persons subject to the authority of the paterfamilias, and especially women, were more likely to recur to demon possession to soften the tensions of the patriarchal family.

(Guijarro 2002:165)

In die eerste-eeuse Mediterreense wêreld was duiwelsbesetenheid en ander geestesiektes 'n sosiaal-aanvaarbare wyse om sosiale konflik, en veral konflik in die patriargale familie, te hanteer (Davies 1995:81). Jesus se eksorsismes en gesondmakings van duiwelbesetenheid en ander geestesiektes (kyk bv Mark 1:21-28; 5:1-20; 7:24-30; 9:14-27) was dus kritiek op die familie as patriargale instelling, in besonder die gelegitimeerde misbruik van mag wat deur hierdie instelling moontlik gemaak is. Sy eksorsismes en gesondmakings was daarmee saam ook 'n bedreiging vir die aanvaarde sosiale orde van sy tyd (Guijarro 2002:166). Die feit dat sowel die Romeinse elite (Luk 13:31-32), die Joodse elite (hier die Fariseërs, vgl Mark 3:3:21-30) en gewone dorpsmense (Mark 5:17) ${ }^{17}$ negatief ten opsigte van Jesus se eksorsismes

\footnotetext{
${ }^{17}$ Horsley oordeel dat die twee gesondmakings wat op die genesing van die besetene van Gerasa (Mark 5:1-20) volg, te wete die vrou wat vir twaalf jaar aan bloedvloeiing gelei het en die twaalfjaaroue dogtertjie van Jaïrus (Mark 5:21-43) ook toon dat vroue, en nie mans nie, gesien moet word as voorbeelde van ware dissipels (kyk weer Afd 4.2.2 hierbo). Hy formuleer hierdie standpunt soos volg: "[T] he woman who had been hemorrhaging for twelve years and the twelve-year old woman (whose father is head of a village assembly) are not simply individuals, but figures representative of Israel, which is bled under the Roman imperial order and indeed is virtually dead. Through the hemorrhaging woman's own trusting initiative, she is healed, while the young woman who is dying just as she reaches child-bearing age is restored to life, presumably including reproductive power" (Horsley 2003:303; sy beklemtoning). In hierdie opsig is hierdie twee gesondmakings kritiek op die patriargale familie en patriargale magstrukture in die tyd van Jesus.
} 
gestaan het, bevestig dat selfs in Jesus se gesondmakings kritiek teenoor uitbuitende magstrukture uitgespreek is (kyk ook Carter 2006:41-43). En vir Jesus was die patriargale familie een daarvan.

\section{JESUS EN DIE HUWELIK}

\subsection{Weer eens: Wat het Jesus gesê?}

In terme van bogenoemde beskrywing van Jesus se houding teenoor die patriargale familie, en veral die posisie van die vrou in die familie (en by implikasie in die huwelik), word geoordeel dat die volgende, in terme van $Q$ 16:18, Markus 10:2-12//Matteus 19:3-12, saaklik na Jesus teruggevoer kan word: Fariseërs, op grond van die toegewing (van Moses) in Deuteronomium $24: 1$, het by geleentheid Jesus gevra of ' $n$ man van sy vrou mag skei. Jesus se antwoord hierop (my parafrase) was soos volg: Dit is as gevolg van die hardheid van harte dat hierdie bepaling aanvaar word. Voor Moses was dit anders. God het man en vrou gemaak, en wanneer 'n man en 'n vrou trou, moet 'n man sy vader en moeder verlaat en saam met sy vrou gaan woon, en hulle twee sal een word. As gevolg van hierdie verbintenis is die implikasie dat 'n man wat van sy vrou skei teenoor sy vrou egbreuk pleeg, en 'n vrou wat van haar man skei pleeg teenoor haar man egbreuk. Die huwelik het dus die potensiaal om slagoffers te skep, en daarom is dit dalk beter om nie te trou nie, maar selibaat te bly.

\subsection{Wat het Jesus bedoel?}

Indien aanvaar sou word dat bogenoemde wel dit is wat Jesus oor die huwelik gesê het, is die logiese vraag wat sy bedoeling daarmee was. In 'n poging om hierdie vraag te beantwoord moet daar, as vertrekpunt, erns met die volgende kenmerkende karakteristiek van die eerste-eeuse Mediterreense wêreld gemaak word:

"Religion", as we call it, was thoroughly embedded in kinship, fictive kinship, and political groupings .... Hence it become very difficult to discuss the "religion" of a particular Mediterranean group apart from a characterization of their patterns of kinship and marriage, their social organization and catchment, and their relationship with their neighbors.

(Kloppenborg 1990:186)

Die verband tussen godsdiens, sosiale organisasie, familie en huwelik in die eerste-eeuse Mediterreense wêreld kan kortliks soos volg beskryf word: Die 


\title{
Die huwelik in die eerste-eeuse Mediterreense wêreld (III)
}

Jodedom van die tweede tempeltydperk se grondnarratief was tekste soos Levitikus 19:2 (wees heilig soos Ek, julle God, heilig is). God se heiligheid was geleë in sy skeppingsorde, 'n skeppingsorde waarin aan elke faset van die skepping 'n bepaalde plek of tyd toegeken is. Om heilig soos God te wees het vir die Jood beteken dat die skeppingsorde van God in elke faset van alle sosiale geledinge gerepliseer moes word (kyk Van Eck 2005:197-206). In die woorde van Douglas (1966:51): "Holiness ... involves keeping distinct the categories of creation; it involves correct definition, discrimination and order".

In die eerste-eeuse Mediterreense wêreld het die familiale instelling primêr uitdrukking aan die replisering van God se skeppingorde gegee:

\begin{abstract}
In ... the ... Mediterranean world ... the centrally located institution maintaining societal existence is kinship and its sets of interlocking rules. This results in the central value of familism. The family or kinship group is central in societal organization; it is the primary focus of personal loyalty and it holds supreme sway over individual life.
\end{abstract}

(Malina 1989:131; sy beklemtoning)

Die huwelik, op sy beurt weer, was produk van die familie as dominante instelling wat uitdrukking aan God se heiligheid gegee het. Die posisie van die vrou was weer produk van die verstaan van die huwelik. In kort: 'n bepaalde verstaan van God se heiligheid het aan die familiale instelling dominansie verleen, die dominansie van die familiale instelling het die huwelik as patriargaal gelegitimeer, en so het die patriargale huwelik die minderwaardigheid van die vrou gelegitimeer.

Jesus het egter God se heiligheid anders verstaan (kyk veral Q 6:36= Matt 5:48//Luk 6:36). Vir Jesus was God se heiligheid God se barmhartigheid (Q 11:42 = Luk 11:42//Matt 23:23). Hierdie verstaan van God se barmhartigheid het uitdrukking gevind in Jesus se houding teenoor die patriargale familie, die vrou en die kind.

Met bogenoemde as agtergrond, kan Jesus se antwoord aan die Fariseërs oor die interpretasie van Deuteronomium 24:1-2 waarskynlik soos volg (in parafrastiese vorm) uitgedruk word: Julle sê, op grond van die wet van Moses (Deut 24:1) dat 'n man aan sy vrou 'n skeibrief kan gee. Die rede vir hierdie gebruik is die hervormings van Esra en Nehemia na die ballingskap ${ }^{18}$ waar 'n ideologie van "heilige land, heilige saad en heilige volk" beteken het

\footnotetext{
${ }^{18}$ Met ander woorde, aan die begin van die Tweede Tempel-tydperk, of dan, die aanvang van die defensiewe huwelikstrategie wat die Joodse tydperk kenmerk (kyk weer Van Eck 2007a:81-101).
} 
dat alle Joodse mans - wat met "vreemde vroue" getroud was - verplig was om van hierdie vrouens te skei. Die huwelik het dus in diens gestaan van 'n bepaalde ideologie (en verstaan van God!), maar die gevolg daarvan was die weerloos laat van vrouens en kinders. ${ }^{19}$ Wanneer 'n man sy vrou om hierdie redes skei, en hy trou weer, pleeg hy egbreuk.

Dit pla julle nie, want die gebooie van mense is vir julle belangriker as die gebod van God (vgl Markus 7:13 ${ }^{20}$ ). Julle glo die vrou is minderwaardig teenoor die man, dat eer manlik is, en dat die vrou in diens van die eer van die man staan. Daarom is die huwelik vir julle patrilokaal, hiërargies, androsentries en selfs poligamies. Daarom kan die man nie teenoor sy vrou egbreuk pleeg nie, en mag die man aan sy vrou 'n skeibrief gee wanneer sy eer op die spel is. In wese kom dit daarop neer dat julle 'n instelling geskep het wat die marginalisering van vroue en die misbruik van mag legitimeer.

Maar van die begin af was dit nie so nie. Moses se toestemming oor die gee van 'n skeibrief was die gevolg van julle verstaan van God se heiligheid en die huwelikshervormings onder Esra en Nehemia net na die ballingskap. Met die oog op 'n heilige volk gebore uit heilige saad in 'n heilige land was die mans toe beveel om van alle "vreemde vroue" te skei (kyk bv Esra 9 en 10; Bossman 1979:32-38; kyk ook Van Aarde 2001a:131). Dit het beteken dat vrouens weerloos gelaat is - asook kinders.

Verstaan teen hierdie agtergrond is Jesus se antwoord op die vraag oor egskeiding dus in wese kritiek op die Fariseërs se verstaan van God, hulle bepaalde replisering van God se heiligheid, die legitimering van die patriargale familie, asook die legitimering van die siening van die vrou en kind as minderwaardige besittings.

Vir God is daar egter nie 'n verskil tussen man en vrou nie. Daarom, indien 'n man en vrou trou, behoort die man sy pa en ma te verlaat en saam met sy vrou gaan woon. Anders is die huwelik patrilokaal, waar die vrou as minderwaardige inwonende vreemdeling gereken word. Verder kan ook die vrou van haar man skei, en die man kan ook teenoor sy eie vrou egbreuk pleeg. Ek bevraagteken dus julle hiërargiese en androsentriese legitimering

\footnotetext{
${ }^{19}$ Dit is belangrik om raak te sien dat Jesus se gebruik van Genesis 1:27 en Genesis 2:24, in sy antwoord aan die Fariseërs, nie verstaan moet word dat Jesus die huwelik skeppingsordelik verstaan nie. Soos in die geval van byvoorbeeld Markus 7:8 en 13, het ons hier te make met Jesus se "soort Skrifgebruik". In Markus 7:1-13 (waar die Fariseërs aan Jesus die vraag stel oor eet met onrein hande - kyk in die besonder Mark 7:5) antwoord Jesus hulle deur verder terug te gaan as die "oorgelewerde gebruike van die voorgeslagte" Jesus gryp terug na Eksodus 20:12 (Deut 5:16) en Eksodus 21:17 (Lev 20:9). Omdat Jesus teruggaan na voor die gebruike van die voorgeslagte, dra sy interpretasie meer gewig. In antwoord op die vraag van die Fariseërs oor hulle interpretasie van Deuteronomium 24:1 doen Jesus presies dieselfde - Hy gryp terug na Genesis 1:27 en Genesis 2:24,. "Van die begin af was dit nie so nie" beteken voor Moses - 'n argument wat meer gewig dra as dié van die Fariseërs.
}

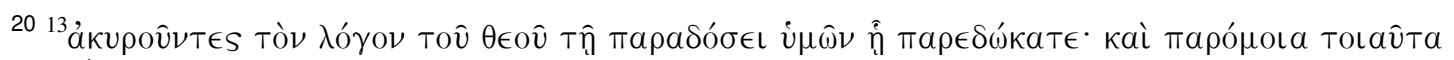

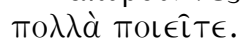


van die huwelik. Inteendeel. Julle het 'n instelling geskep waaruit slagoffers gebore word. Van so 'n instelling kan ek nie deel wees nie. Selibaatskap is daarom beter (Davies \& Allison 2004:26; Guijarro 2004:114; Nolland 2005:767, 782).

In die woorde van Kloppenborg (1990:196):

The mode of Jesus' discourse (oor die huwelik - EvE) is not directly moralizing .... Rather than offering simple prescriptions the point of this saying ... was to expose and lampoon certain structures of social exchange which from the point of view of God's reign were false and debilitating.

(Kloppenborg 1990:196)

Jesus se antwoord op die vraag van die Fariseërs kom dus in wese daarop neer dat Hy eintlik niks oor die huwelik, egskeiding, egbreuk en hertrou sê nie. ${ }^{21}$ Meer spesifiek: Jesus sê nie of iemand mag of nie mag skei nie. Vir Jesus skep die vraag die geleentheid om dit wat agter die eerste-eeuse Mediterreense verstaan van die huwelik lê, en nie aan sy verstaan van God se wil voldoen nie, te ontbloot: eer en status as sogenaamde dominante middel, die patriargale familie, die dominansie van die familiale instelling as uitdrukking van die verstaan van God se heiligheid, die legitimering van 'n hiërargiese samelewing, en die gepaargaande marginalisering van vroue en kinders (kyk ook Horsley 1993:235-236).

Om dus Jesus se uitspraak in Q16:18//Markus 10:11//Matteus 19:9 te verstaan as 'n blote verbod op egskeiding, sou myns insiens nie reg aan hierdie uitspraak laat geskied nie. Dit gaan oor veel meer, 'n afwys van androsentriese eer wat die nie-menswaardige behandeling van vroue, kinders en nie-dominante mans legitimeer. Dit gaan oor die afwys van 'n bepaalde verstaan van die heiligheid van God, en die beklemtoning van God se barmhartigheid. Dit gaan oor die koninkryk van God wat anders as die tempelkoninkryk van die eerste-eeuse Mediterreense wêreld is. Dit gaan oor barmhartigheid teenoor heiligheid. Dit gaan oor die koninkryk teenoor kultuur. Dit gaan oor Jesus se uitspraak in Markus 1:15: Bekeer julle en glo in die evangelie, want die koninkryk is hier!

\footnotetext{
${ }^{21}$ In die woorde van Kloppenborg (1990:196): "[T]he mode of Jesus' discourse is not directly moralizing - even in the case of the divorce saying .... Jesus' message cannot be conveniently compartmentalized into discrete or non-contiguous realms. It is equally clear that we can no longer think of a Jesus who preached a purely religious message of interiorized piety, and avoided social questions".
} 


\section{GEVOLGTREKKING}

Jesus was negatief teenoor die huwelik as instelling. Vir Jesus het die huwelik as instelling nie alleen die marginalisering van vrouens en kinders gelegitimeer nie, maar ook as instelling die moontlikheid van slagoffers daargestel. Die huwelik as instelling het bepaalde mense ontmagtig waarvan Deuteronomium 24:1 'n goeie voorbeeld is. Daarom was Hy van oordeel dat dit miskien beter is om nie te trou nie (vgl Matt 19:12).

Sou Jesus van 'n vrou verwag het om in 'n huwelik te bly waarin sy as besitting gereken en as minderwaardige geag is? Heel waarskynlik nie. Sou Jesus van 'n man en 'n vrou verwag het om saam in 'n huwelik te bly terwyl hulle geen keuse gehad het wat huweliksmaats betref nie? Heel waarskynlik nie. Wat ons wel sou kon aflei is dat Jesus van oordeel was dat ' $n$ man wat sy vrou om die verkeerde redes skei (soos in die geval van Deut 24:1 in terme van die opdrag van Esra en Nehemia) en dan weer trou, nie alleen egbreuk pleeg nie, maar egbreuk teen sy eie vrou pleeg (Mark 10:11). 'n Verdere moontlike standpunt van Jesus - ook teen die konvensies van sy tyd in - was dat 'n vrou ook egskeiding kon inisieer (vgl Mark 10:12). Hier moet ons egter raaksien dat beide hierdie standpunte van Jesus alleen verstaan kan word teen die agtergrond van sy afwysing van die marginalisering van enige persoon - veral vroue en kinders.

Meer kan daar egter nie gesê word nie, omdat Jesus niks hieroor gesê het nie. Daar sou selfs gesê kon word dat Jesus eintlik niks oor die huwelik gesê het nie (vgl ook Craffert 2006:20). Feit is: dit wat Jesus oor die huwelik gesê het kan nie gebruik word om vandag etiese uitsprake oor egskeiding, egbreuk en hertrou te maak nie. Dit was immers nie die bedoeling van Jesus se uitsprake oor hierdie sake nie. Sy bedoeling was eerder om die uitwasse van die huwelik as instelling in sy tyd uit te wys.

Tog beteken dit nie dat die evangelie niks oor die huwelik vandag te sê het nie. Op die vraag of mense tog maar moet trou, sou Jesus heel waarskynlik die volgende gesê het: indien daar vir die huwelik as instelling gekies word moet man en vrou in die huwelik as gelykes geag word. Die huwelik, soos enige ander instelling waarvoor gekies mag word, behoort mense te bemagtig. Dit beteken dat die huwelik nooit patriargaal, poligamies, hiërargies of patrilokaal kan wees nie. En onthou: die huwelik as instelling hou altyd die moontlikheid en versoeking in om op 'n sogenaamde legitieme wyse slagoffers langs die pad te los. Net so dra die verabsolutering van die huwelik as instelling in homself die potensiaal om teen ander se seksualiteit te diskrimineer.

Wat die kerk vandag nodig het is 'n eietydse huweliksetiek wat met die Jesus-saak se evangeliese (nie Bybelse) waardes gevul word. Vir hierdie doel 
is die kultuurgebonde Bybelse kategorieë nie baie bruikbaar nie. Kultuur mag nooit kanon word nie. Alles in die Bybel is nie evangelie nie.

\section{Literatuurverwysings}

Bossman, D 1979. Ezra's marriage reform: Israel redefined. BTB 9, 32-38.

Brooten, B J 1996. Love between women: Early Christian responses to female homoeroticism. Chicago, IL: University of Chicago Press.

Carter, W 2006. The Roman Empire and the New Testament: An essential guide. Nashville, TN: Abingdon.

Collins, R F 1992. Divorce in the New Testament. Collegeville, MN: The Liturgical Press.

Corley, K E 2002a. Women and the historical Jesus: Feminist myths of Christian origins. Santa Rosa, CA: Polebridge.

Corley, K E 2002b. Gender and class in the teaching of Jesus: A profile, in Hoover, R W (ed), Profiles of Jesus, 137-160. Santa Rosa, CA: Polebridge.

Countryman, L W 1988. Dirt, greed and sex: Sexual ethics in the New Testament and their implications for today. Philadelphia, PA: Fortress.

Craffert, P F 2006. Godsdiensaktueel: Wat sê die Bybel van die huwelik? Beeld, 3 Desember 2006, bl 20.

Crossan, J D 1986. Sayings parallels: A workbook for the Jesus tradition. Philadelphia, PA: Fortress.

Crossan, J D 1991. The historical Jesus: The life of a Mediterranean Jewish peasant. San Francisco, CA: HarperSanFrancisco.

Davies, S 1995. Jesus the healer. London: SCM Press.

Davies, W D \& Allison, D C 2004. A critical and exegetical commentary on the gospel according to Matthew, Vol III: Commentary on Matthew, 19-28. London: T \& T Clark International. (ICC.)

Donahue, J R \& Harrington, D J 2002. The Gospel of Mark. Collegeville, MN: The Liturgical Press. (Sacra Pagina, Volume 2.)

Douglas, M T 1966. Purity and danger: An analysis of the concepts of pollution and taboo. London: Routledge \& Kegan Paul.

Dreyer, Y 2002. Vroue in die Sinoptiese Evangelies - méér as dekoratiewe karakters. HTS 58(4), 1679-1706.

Dreyer, Y [2007]. 'n Manlike vertellersperspektief op vroue in die Evangelie van Matteus: 'n Gender-kritiese uitleg, in Nortje-Meyer, L (red), 'n Gender Bybelkommentaar. Kaapstad: Lux Verbi. (Tans ongepubliseer.)

Elliger, K \& Rudolph, W 1983 (eds). Biblia Hebraica Stuttgartensia. Stuttgart: Württembergische Bibelgesellschaft.

Funk, R W 1990. New Gospel parallels, Vol 1, 2: Mark. Sonoma: Polebridge.

Funk, R W, Hoover, R W \& The Jesus Seminar 1993. The five gospels: The search for the authentic words of Jesus. New York: Macmillan.

Guijarro, S 2001. Kingdom and family: A contribution to the study of the historical Jesus, in Pilch, $\mathrm{J} \mathrm{J}(\mathrm{ed})$, Social scientific models for interpreting the Bible: Essays by the Context Group in honor of Bruce J Malina, 210-238. Leiden: Brill. 
Guijarro, S 2002. The politics of exorcism, in Stegemann, W, Malina, B J \& Theissen, G, The social setting of Jesus and the Gospels, 159-174. Minneapolis, MN: Fortress.

Guijarro, S 2004. The family in the Jesus movement. BTB 34(3), 114-121.

Harrington, D J 1991. The Gospel of Matthew. Collegeville, MN: The Liturgical Press. (Sacra Pagina, Vol 1.)

Hellerman, H 2001. The ancient church as family. Minneapolis, MN: Fortress.

Hollenbach, P W 1981. Jesus, demoniacs, and public authorities: A socio-historical study. JAAR 49, 561-588.

Horsley, R A 1993. Jesus and the spiral of violence: Popular Jewish resistance in Roman Palestine. Minneapolis, MN: Fortress.

Horsley, R A 2003. Feminist scholarship and postcolonial criticism: Subverting imperial discourse and reclaiming submerged histories, in Matthews, S, Kittredge, C B \& Johnson-Debaufre, M (eds), Walk in the ways of wisdom: Essays in honor of Elisabeth Schüssler Fiorenza, 297-317. Harrisburg, PA: Trinity Press International.

Howes, L \& Van Aarde 2005a. 'n Pre-kanonieke bron van die leë graf tradisie. Ekklesiastikos Pharos (New Series 16) 87; 301-324.

Howes, L \& Van Aarde, A G 2005b. Handelinge se uitbeelding van die rol van vroue in die vroeë kerk. HTS 61(4), 1183-1208.

Instone-Brewer, D 2002. Divorce and remarriage in the Bible: The social and literary context. Grand Rapids, MI: Eerdmans.

Johnson-Debaufre, M 2005. Jesus among her children: $Q$, eschatology, and the construction of Christian origins. Cambridge: Harvard University Press. (Harvard Theological Studies 55.)

Karris, R J 2002. Women and discipleship in Luke, in Levine, A-J \& Blickenstaff, M (eds), A feminist companion to Luke, 23-43. London: Sheffield Academic Press. (Feminist Companion to the New Testament and Early Christian Writings 3.)

Kloppenborg, J S 1990. Alms, debt, and divorce: Jesus' ethics in their Mediterranean context. Toronto Journal of Theology 6/2, 182-200.

Kloppenborg, J S 1988. Q parallels: Synopsis, critical notes \& concordance. Sonoma: Polebridge.

Lang, B 1990. Charisma and the disruption of family in early Christianity, in Kohl, K $\mathrm{H}$, Muzinski, $\mathrm{H}$ \& Strecker, I, Die vielvalt der kultur: Ethnologische aspekte von verwandschaft, kunst und weltanfassung. Ernst Wilhelm Müller zum 65 Geburtstag, 278-287. Berlin: Diter Riemer Verlag.

Loader, W 2004. The Septuagint, sexuality, and the New Testament: Case studies on the impact of the LXX in Philo and the New Testament. Grand Rapids, MI: Eerdmans.

Loader, W 2005. Sexuality and the Jesus tradition. Grand Rapids, MI: Eerdmans.

Malina, B J 1981. The New Testament world: Insights from cultural anthropology. Louisville, KY: John Knox.

Malina, B J 1989. Dealing with biblical (Mediterranean) characters: A guide for US consumers. BTB 19(4), 127-141.

Malina, B J 1999. Criteria for assessing the authentic words of Jesus: Some specifications, in Chilton, B D \& Evans, C A, Authenticating the words of Jesus, 27-45. Leiden: Brill. 
Malina, B J \& Rohrbaugh, R L 1992. Social science commentary on the Synoptic Gospels. Minneapolis, MN: Fortress.

Malina-Jacobs, D 1993. Beyond patriarchy: The images of family in Jesus. New York: Paulist.

Marxsen, W 1968. Introduction to the New Testament: An approach to its problems. Philadelphia, PA: Fortress.

Meier, J P 1991. A marginal Jew: Rethinking the historical Jesus, Vol 1. New York: Doubleday.

Newsom, C A \& Ringe, S H (eds). Women's Bible Commentary. Louisville, KY: Westminster.

Nolland, J 2005. The gospel of Matthew: A commentary on the Greek text. Grand Rapids, MI: Eerdmans. (NIGTC.)

Osiek, C 2006. The New Testament teaching on family matters. HTS 62(3), 819-843.

Pfohl, S 1985. Images of deviance and social control: A sociological history. New York: McGraw-Hill.

Pilch, J 1993. "Beat his ribs while he is young" (Sir 30:12): A window on the Mediterranean world. BTB 23, 101-113.

Robinson, J M, Hoffmann, P \& Kloppenborg, J S 2000. The critical edition of Q: Synopsis including the Gospels of Matthew and Luke, Mark and Thomas with English, German, and French translations of $Q$ and Thomas. Leuven: Peeters.

Schaberg, J 1998. Luke, in Newsom \& Ringe 1998:363-380.

Sanders, J T 1993. Schismatics, sectarians, dissidents, deviants: The first hundred years of Jewish-Christian relations. Valley Forge, PA: Trinity Press International.

Schüssler Fiorenza, E 1979. Marriage and discipleship. The Bible Today April 1979, pp 2027-2034.

Schüssler Fiorenza, E 1980. Der Beitrag der Frau zur urchristlichen Bewegung: Kritische Überlegungen zur Rekonstruktion urchristlicher Geschichte, in Schottroff, W \& Stegemann, W (Hrsg), Traditionen der Befreiung: Sozialgeschichte Bibelauslegungen, Band 2: Frauen in der Bibel, 60-90. München: Kaiser.

Schüssler Fiorenza, E 1982. Discipleship and patriarchy: Early Christian ethos and Christian ethics in a feminist theological perspective, in Rasmussen, $L$ (ed), The Annual of the Society of Christian Ethics: Selected papers, 131-172. Waterloo: Council of the Study of Religion.

Schüssler Fiorenza, E 1992. In memory of her: A feminist theological reconstruction of Christian origins. New York: Crossroad Books.

Steyn, G J 1996. Pretexts of the second table of the Decalogue and early Christian intertexts. Neotestamentica 30(2), 451-464.

Tatum, W B 1999. In quest of Jesus. Nashville, TN: Abingdon.

Theissen, G 1983. The miracle stories of the early Christian tradition. Edinburgh: T \& T Clark.

Theissen, G \& Mertz, A 1998. The historical Jesus: A comprehensive guide. Minneapolis, MN: Fortress.

Tolbert, M A 1998. Mark, in Newsom \& Ringe 1998:350-362.

Van Aarde, A G 2000. Understanding Jesus' healings. Scriptura 74, 223-236. 
Van Aarde, A G 2001a. Fatherless in Galilee: Jesus as child of God. Harrisburg, PA: Trinity Press International.

Van Aarde 2001b. The "cause of Jesus" (Sache Jesu) as the Canon behind the Canon. HTS 57(1\&2), 148-171.

Van Aarde A G 2004. Jesus' affection toward children and Matthew's tale of two kings. Acta Theologica 24(2), 127-146.

Van Aarde, A G 2005. Christologie van die Nuwe Testament: Die historiese Jesus. Ongepubliseerde studiehandleiding, Universiteit van Pretoria.

Van Eck, E 1995. Galilee and Jerusalem in Mark's story of Jesus: A narratological and social-scientific reading. Pretoria: Kital (HTS Suppl 7.)

Van Eck, E 2006. Inleiding en teologie: Evangelies (Matteus ). Ongepubliseerde studiehandleiding, Universiteit van Pretoria.

Van Eck, E 2007a. Die huwelik in die eerste-eeuse Mediterreense wêreld (I): Vroue in 'n man se wêreld. HTS 63(1), 81-101.

Van Eck, E 2007b. Die huwelik in die eerste-eeuse Mediterreense wêreld (II): Huwelik, egbreuk, egskeiding en hertrou. HTS 63(1), 103-128.

Wallace, M I 2006. The rule of love and the testimony of the Spirit in contemporary Biblical hermeneutics, in Padgett, A G \& Keifert, R K (eds), in But is it all true? The Bible and the question of truth, 66-85. Grand Rapids, MI: Eerdmans.

Wevers, J W 1974 (ed). Septuaginta. Vetus Testamentum Graecum I: Genesis. Göttingen: Vandenhoeck \& Ruprecht.

Wevers, J W 1977 (ed). Septuaginta. Vetus Testamentum Graecum III, 2: Deuteronomium. Göttingen: Vandenhoeck \& Ruprecht.

Wevers, J W 1991 (ed). Septuaginta. Vetus Testamentum Graecum ii, 1: Exodus. Göttingen: Vandenhoeck \& Ruprecht. 